\title{
Late Wenlock graptolite-bearing tuffaceous sandstone from Bornholm, Denmark
}

\author{
MERETE BJERRESKOV AND KARL AGE JØRGENSEN
}

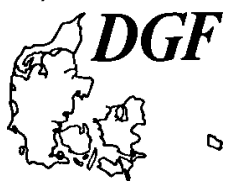

Bjerreskov, M. \& Jørgensen, K. A.: Late Wenlock graptolitebearing tuffaceous sandstone from Bornholm, Denmark. Bull. geol. Soc. Denmark, vol. 31 pp. 129-149, Copenhagen, March 7th, 1983.

Late Wenlock (Silurian) graptoliferous dark grey mudstone and tuffaceous sandstone lithofacies occur, mainly as loose boulders, at the southeast coast of Bornholm. The mudstone may be estimated to represent a $25 \mathrm{~m}$ thick sequence, and contains a graptolite fauna indicating the Cyrtograptus lundgreni Zone. The fauna is correlated with sequences of similar age from other areas, specially from Scania. Monograptus flemingi and Pristiograptus dubius pseudodubius are virtually the only species in the tuffaceous sandstone, some of which were deposited by turbidity currents. There is evidence from the taphonomy and diversity of the sandstone graptolites to suggest that the two species lived at a lower level in the water column than other, coexisting species. Size-frequency analyses are inconclusive as to whether or not the fauna in the tuffaceous sandstone represents a rapidly buried life-assemblage. The tuffaceous sandstone samples represent at least 3 airfall water deposited tuff beds and one bed deposited by turbidity current action. Mineral composition and grain-size of the tuffaceous sandstone indicate an origin from plinian eruptions at an estimated distance of about $300 \mathrm{~km}$ from Bornholm, and deposition at a depth of $1000 \mathrm{~m}$ $\pm 300 \mathrm{~m}$, on the outer rim of the Fennoscandian platform. The volcanoes were probably situated on a continent south of Bornholm. The eruption centre later may either have disappeared within the Caledonian foldbelt or have been displaced by early Palaeozoic large-scale strike-slip faults towards the SE, along the SW border of the East-European craton.

M. Bjerreskov, Institut for Historisk Geologi og Palaontologi, Øster Voldgade 10, DK-1350, Copenhagen $K$, Denmark, K. A. Jørgensen, Geological Museum, Øster Voldgade 5-7, DK-1350 Copenhagen K, Denmark, September 29th, 1982.

The presence of boulders of Silurian rocks of sandstone facies and containing graptolites, on the southern coast of Bornholm between Dueodde and the outlet of Øleå (Fig. 1), has been known for many years. The occurrence was first mentioned in the literature by Poulsen (1966), who reported the material as being from the upper parts of the "Retiolites" Beds (defined by Tömquist 1913), and indicating a regression. Later, a sandstone boulder was figured by Poulsen \& Poulsen (1967: fig. 65a).

Recently, a closer examination of the area yielding the Silurian boulders has been made, and material was collected in the summers 1978 , 1979 and 1980. The occurrence of the sandstone boulders is restricted to $1 \mathrm{~km}$ of the beach between Sommerodde and Stenodde. Here the large majority of boulders on the sandy beach comprise light grey tuffaceous sandstones as well as dark grey laminated mudstones. Generally the mudstone appears heterolithic, containing clay and silt laminations; graptolites in the mudstone represent the lundgreni Zone, late Wenlock Series (fig. 6). In addition, a few samples of dark mudstone of late Wenlock age have been collected from exposures in the sea floor at distances up to 300-400 m south of the coast, but unfortunately no tuffaceous sandstone has been found exposed in the sea bottom.

Most of the non-silurian boulders on the beach are grey-green sand- and siltstone of early Cambrian age, most likely originating from faultblocks lying to north-east exposing Cambrian rocks (Gry 1977, map pp. 4-5).

A few boulders of darker grey mudstone containing graptolites of early Wenlock age indicating the centrifugus Zone have been found on the beach. Most likely they originate from the faultblock that exposes early Wenlock mudstone in Øleå (Bjerreskov 1975), and maybe also from exposed mudstone on the sea bottom south of the outlet of Øleå. No Silurian material has been re- 


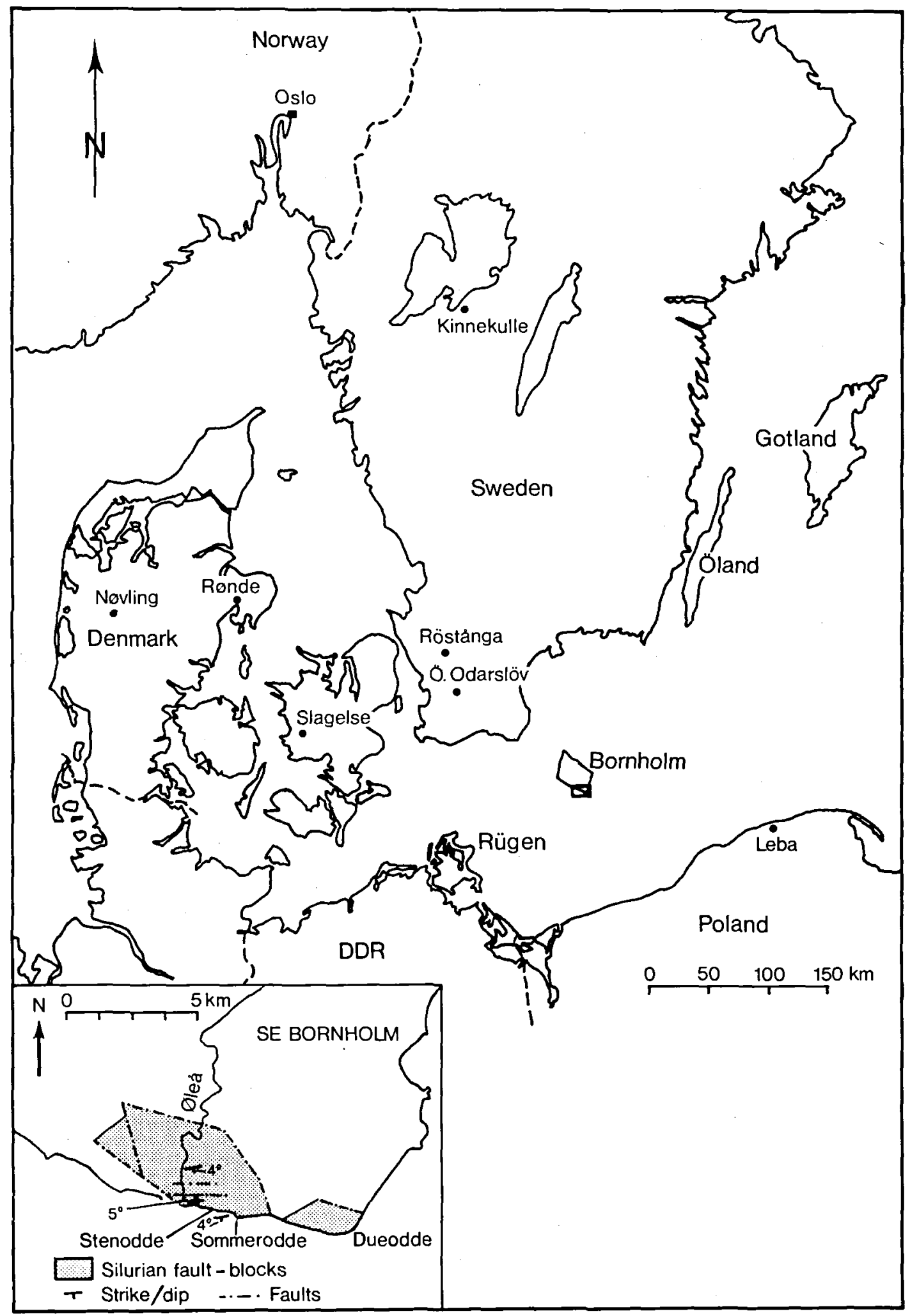

Fig. 1. Location map. The position of Silurian sequences and the faults on Bornholm is based on Gry (1977) and Bjerreskov (1975). 
corded in the area north of the beach, which is covered by Holocene sand dunes several metres thick.

The investigated late Wenlock material comprises about 500 boulders, of which about half are tuffaceous sandstone. Almost all of the investigated material is loose material. Thus we are prevented from working out a sequence with the correct thicknesses and stratigraphic positions of the different beds. However, the fact that the tuffaceous sandstone boulders must have been originally deposited as ash-layers within the mudstone sequence is fairly well indicated by the basal parts of the tuffaceous sandstone boulders often occurring as intraformational breccias with rip-up clasts of the dark grey mudstone.

As the mudstone is more or less continuously exposed in the sea floor up to $300-400 \mathrm{~m}$ from the beach, and the orientation of the strata has the same general strike/dip as the older Silurian beds on shore (see later), it is most probable that the upper Wenlock material is a part of the large Silurian fault-block, of which older strata are exposed in Øleå. The alternative possibility, that it represents a huge block dislocated by the Quaternary glaciers, would appear unlikely.

\section{Sedimentology.}

\section{The tuffaceous sandstone}

The tuffaceous sandstone occurs as more or less angular, flat boulders. In general the boulders have preserved the lower boundary and some of the underlying mudstone, while the upper boundary rarely is preserved.

It is difficult to estimate the number of beds represented among the boulders, but at least two texturally different types are present, and judging from various thicknesses at least 4 beds are represented, of which only one is mudstone clastbearing and distinctly different from the rest.

\section{Texture}

The clast-bearing bed is up to $40 \mathrm{~cm}$ thick. It has a distinct lower boundary against the underlying carbonaceous mudstone, into which scour marks are cut. The lower $5 \mathrm{~cm}$ of the bed contains abun- dant mudstone rip-up clasts up to $7 \mathrm{~cm}$ long, forming an intraformational breccia, which occasionally have been only partly disaggregated from the substratum (plate 1, figs. A, B). The rip-up clasts are angular to subrounded, often elongated and current orientated (plate 1, fig. B). Preserved bedding planes within the clasts show only minor deformation, indicating that the clasts were fairly rigid at the time of disaggregation, though not hardened as the margins have been truncated by impacting crystals. The breccia is overlain by a $1 \mathrm{~cm}$ thick bed containing abundant minute mudstone fragments and this grades into a $1 \mathrm{~cm}$ thick horizon showing indistinct laminae, which in turn is followed by a $3-5 \mathrm{~cm}$ thick horizon of fairly homogeneous matrix material. There is a slight increase in grain-size through the unit. Above this unit a new cycle starts, over an erosional junction, with a bed of rip-up mudstone clasts. The abundance of rip-up clasts, however, has decreased markedly, and a slight decrease in the abundance of graptolites is also observed. In a few large boulders, a third cycle can be distinguished, containing almost no mudstone clasts and graptolites. The upper boundary of this unit has not been seen.

The beds lacking clasts are much thinner than those containing graptolites, at the most $7 \mathrm{~cm}$, but otherwise only 1 to $2 \mathrm{~cm}$. These beds have a rather massive appearance, but the lower part is indistinctly laminated in some (plate 1 , fig. C). In one case, microsized slumping in the lowermost laminae has occurred from the top of a small irregularity in the substratum, but this is overlain by undisturbed laminae, mantling the irregularity (plate 1, fig. D.). The top part of the thinner layers have been found in a few cases, and show only very minor disturbance, indicating that bioturbation was practically absent. A bed in a heterolithic sequence shows evidence of minor redeposition in the upper part of the bed in the shape of small scale cross bedding. The lower boundary of the beds is very distinct, but in some cases crystals can be seen to have impacted into the underlying clay.

\section{Petrography}

Originally the beds were dominated by glass lapilli, shards and igneous minerals, but this as- 

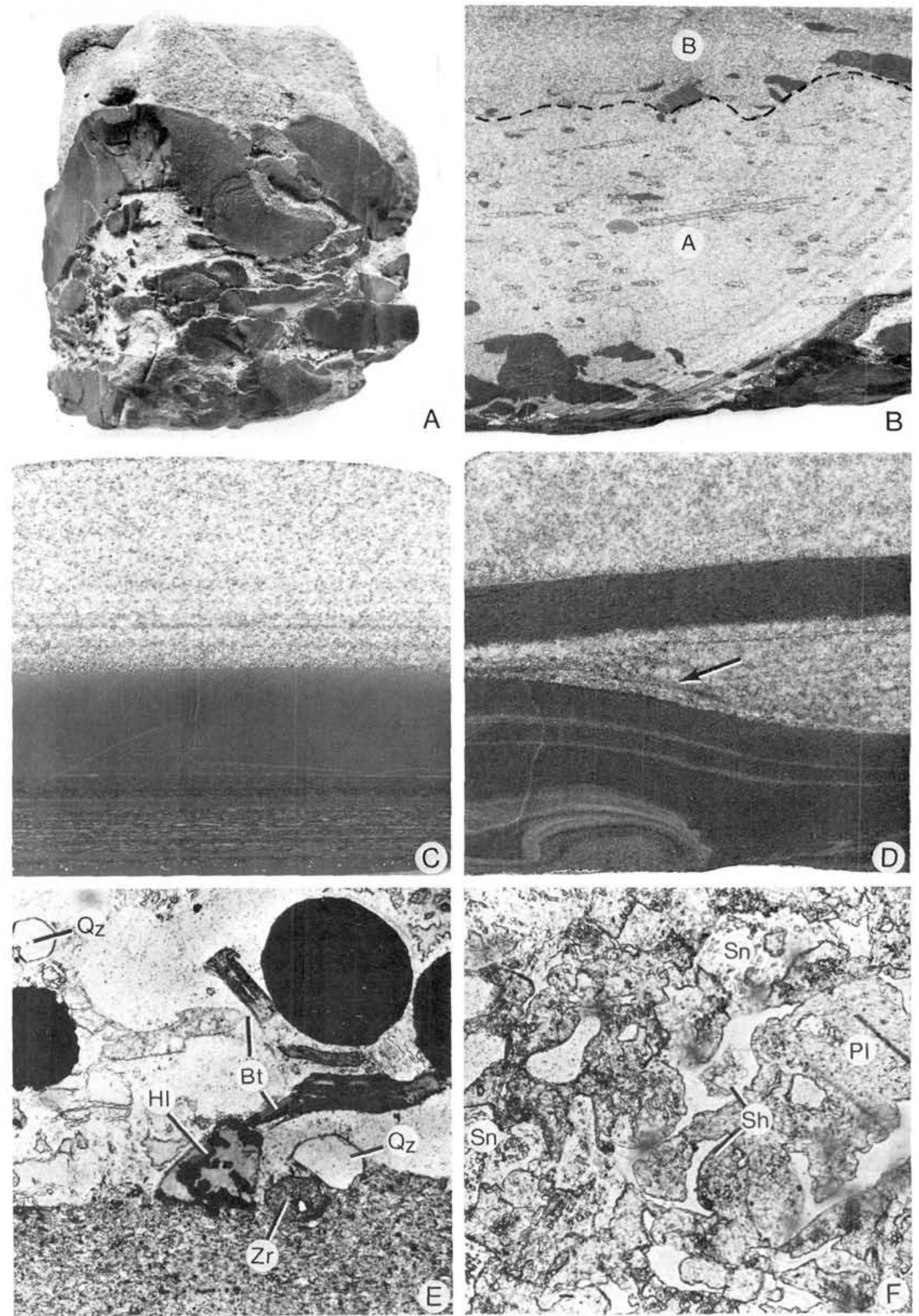
TABLE I. MINERAL COMPOSITIONS.

\begin{tabular}{|c|c|c|c|c|c|}
\hline Type & $\begin{array}{c}\mathrm{FA} \\
\mathrm{Bf} \\
{ }_{\text {core }}\end{array}$ & $\begin{array}{c}\mathrm{FA} \\
\mathrm{Bt} \\
\text { rim }\end{array}$ & $\begin{array}{c}\text { TB } \\
\mathrm{Bt}^{\mathrm{H}} \mathrm{rim}\end{array}$ & $\begin{array}{c}\mathrm{TB} \\
\mathrm{Bt}^{\mathrm{T}}{ }_{\text {core }}\end{array}$ & $\begin{array}{c}\text { FA } \\
S_{\text {alb }}\end{array}$ \\
\hline $\mathrm{SiO}_{2}$ & 34.80 & 32.38 & 29.03 & 30.75 & 67.93 \\
\hline $\mathrm{Al}_{2} \mathrm{O}_{3}$ & 21.77 & 23.50 & 18.85 & 18.61 & 18.91 \\
\hline $\mathrm{TiO}_{2}$ & 1.60 & 0.92 & 2.94 & 4.06 & 0.03 \\
\hline $\mathrm{FeO}^{\dagger}$ & 14.43 & 17.99 & 21.92 & 19.47 & 0.04 \\
\hline $\mathrm{MnO}$ & 0.17 & 0.20 & 0.54 & 0.22 & 0.13 \\
\hline $\mathrm{MgO}$ & 10.66 & 10.53 & 14.17 & 13.54 & 0.08 \\
\hline $\mathrm{CaO}$ & 0.01 & 0.08 & 0.19 & 0.08 & 0.32 \\
\hline $\mathrm{Na}_{2} \mathrm{O}$ & 0.13 & 0.08 & 0.43 & 0.29 & 11.04 \\
\hline $\mathrm{K}_{2} \mathrm{O}$ & 2.53 & 1.73 & 0.73 & 1.75 & 0.02 \\
\hline Sum & 86.10 & 87.41 & 89.10 & 88.77 & 98.50 \\
\hline
\end{tabular}

Explanation: FA, air-foll bed. TB, ash-turbidite bed.

Bt, chloritised biotite phenocryst. Sn $a l b$, albitised sanidine phenocryst. The minerals were analysed with a JEOL Superprobe 733, equipped with a UINK Systems EDS unit. Analyses were corrected with ZAF 4/FLS corrections.

semblage has suffered extensive sea-floor weathering and subsequent diagenesis, resulting in extensive replacements and authigenic mineral formation. The layers are rather crystal-rich with 30 to 50 model \% crystals.

The primary mineral assemblage for all the layers appears to have been sanidine $(58 \%$ of the minerals present $)$ - quarts $(10 \%$ o.m.p. $)$ - plagioclase ( $25 \%$ o.m.p.) - biotite ( $7 \%$ o.m.p.) - amphibole ( $2 \%$ o.m.p.) - pyroxene ? - Fe-Ti-oxides - zircon - apatite with minor interlayer differences in the relative abundance of the minerals, especially the feldspars (plate 1, fig. E). Amphibole and pyroxene are always pseudomorphed by haematite and calcite, while the Fe-Tioxides have been heavily oxidized. The plagioclase is altered to calcite, but is easily recognized because of preserved albite twinning and more slender grains than the sanidine. Sanidine is strongly albitized (table 4), but is recognized by the stubby grains, occasional Karlsbad twinning and abundant fluid inclusions. Optically biotite appears comparatively unaltered, but microprobe analysis (fig. 2; table 1) reveals that most of the elements have suffered extensive leaching, in

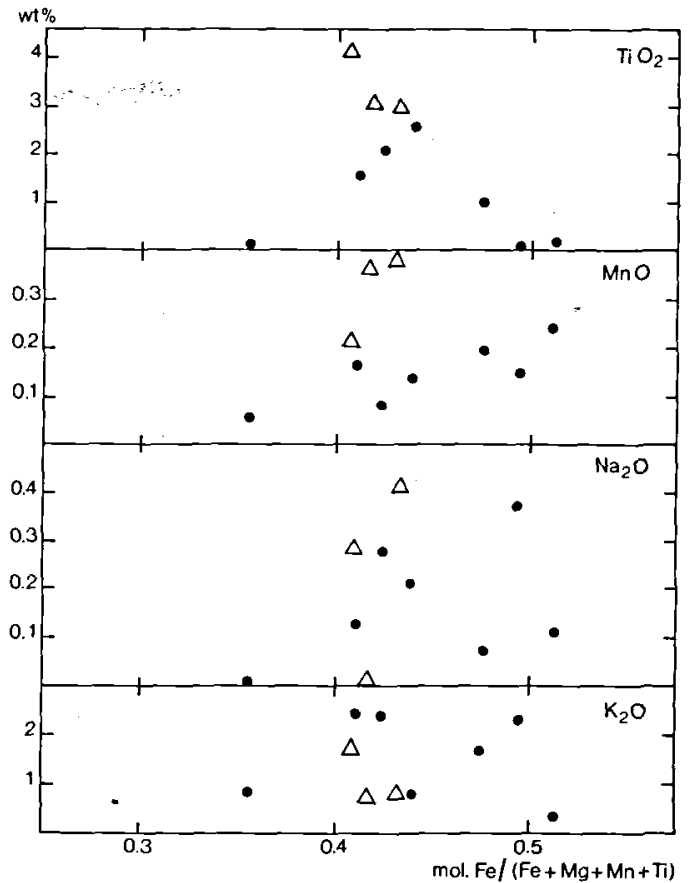

$\triangle$ ASH-TURBIDTE BIOTTES

- AIR-FALL BIOTITES

Fig. 2. Chemical range of $\mathrm{K}_{2} \mathrm{O}, \mathrm{Na}_{2} \mathrm{O}, \mathrm{TiO}_{2}$ and $\mathrm{MnO}$ (weight $\%$ ), against $\mathrm{Mg}$ value ( $\mathrm{mol} \mathrm{Fe} / \mathrm{Fe}+\mathrm{Mg}+\mathrm{Ti}+\mathrm{Mn}$ ) for chloritized biotites from the tuffaceous sandstone, based on EDS analysis with applied ZAF 4/FLS-corrections.

particular affecting $\mathrm{K}_{2} \mathrm{O}$ which has been reduced from a normal level of $9 \mathrm{wt} \%$ to often less than $1 \%$, turning the biotite into a chlorite. In the clast-free beds the biotite is more coherent than in the clast-bearing ones, where the crystals commonly are split into flakes.

In general the glass is totally altered, and in many cases the outlines are destroyed (plate 1 , fig. F), but what is left shows that the lapilli fragments are well vesiculated pumice and the shards of the cuspate T-type, except for one thin layer where more massive shards abound. The glass has

Plate I. Sedimentary structures.

A: Bottom part of ash-turbidite showing concentration of mudstone clasts. Height of sample $12.5 \mathrm{~cm}$.

B: Bottom part of ash-turbidite sectioned parallel to the flow aligned graptolites. The section cuts the two lowermost flow-units (A and B), and shows the occurrence of abraded clasts. Height of sample $8.5 \mathrm{~cm}$.

C: Laminated ash-fall bed, overlying very fine-grained mudstone. In the lower part of the mudstone coarser laminae. Height of sample $5 \mathrm{~cm}$.

D: Two closely spaced ash-falls, the lower laminated and burying a convolute bedded mudstone. Arrow points to microsized slump in the lowermost ash-laminae. Height of sample $4.3 \mathrm{~cm}$.

E: Microphotograph mudstone-fall transition, upper layer in D, showing settled phenocrysts of quartz (Qz), biotite (Bt), amphibole pseudomorph (HI) and zircon (Zr), Black spheres are framboidal pyrite. Width of field $0.6 \mathrm{~mm}$.

F: Microphotograph of pseudomorphed shards (Sh), sanidine (Sn) and plagioclase (Pl). From same as E. Width of field 1.5 mm. 

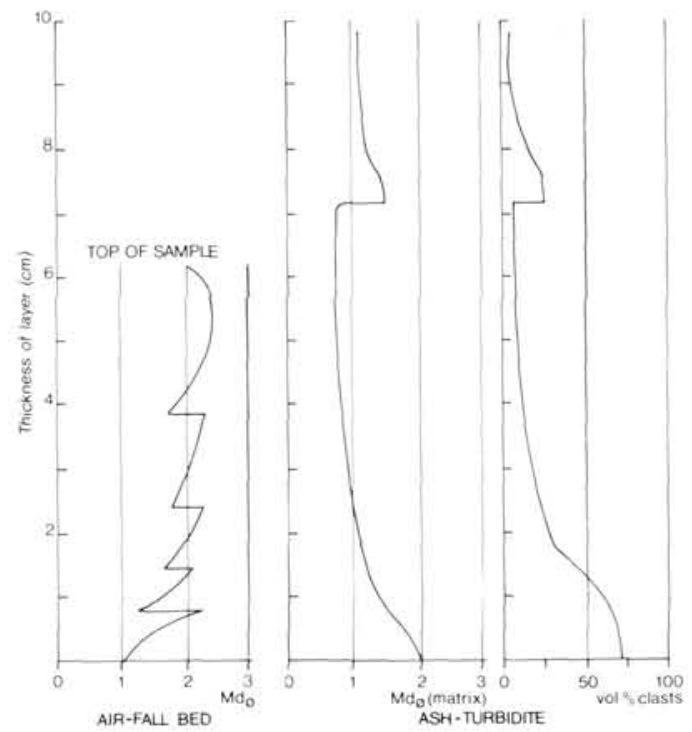

Fig. 3, Grain size $(M d \varnothing)$ variations through the thickest laminated ash bed and the clast-bearing bed. The diagram is constructed from a number of grain-measurements at critical levels from bottom to top in thin-sections crossing the layers.

now been leached and crystallized and has been replaced by opal and silica gels. Xenolithic fragments constitute only a very minor part of the material. They have been strongly altered and in many cases disaggregated. The majority of the fragments are coarsely crystalline salic material, with only quarts and occasionally feldspar (microcline and plagioclase) preserved. A few mafic fragments of presumed andesite/basaltic-andesite with pilotaxitic texture have been found. None of the lithic fragments found exceeds $0.3 \mathrm{~mm}$ in size.

The original grain-size distribution for the tephra layers is difficult to reconstruct, but considering the crystal size distribution and the crystal interspacing a rough estimate can be made (fig. 3). This clearly shows the difference between the clast-bearing and the laminated types, with the slightly increasing grain-size for the first, and the decreasing oscillations for the second. On average, the clast-bearing type has an Md around $0.5 \mathrm{~mm}$ and a rather poor sorting while the laminated type ranges from 0.2 to $0.3 \mathrm{~mm}$, with a much better sorting.

The lamination is due to concentration of phenocrysts and rather massive angular shards at certain levels, which is further enhanced by framboidal pyrite (see below). In the lowermost part

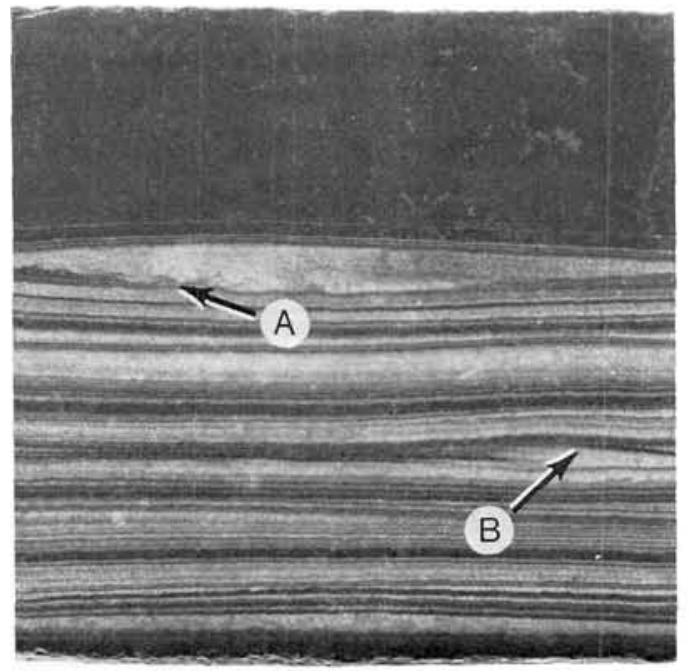

Fig. 4. Heterolithic mudstone showing microscale flame structures (A) and cross bedding (B). Height of sample $3.5 \mathrm{~cm}$.

of the beds there is a marked concentration of zircons.

The tephra layers are mainly silica cemented, but with patches of calcite cementation, except for the lowermost unit of the clast-bearing bed which is mainly calcite cemented. Framboidal pyrite is frequent in the tephra layers and apparently grew in pore voids during cementation and early sea-floor weathering. Compaction of the beds has only been very minor, as shown by the well preserved shard outlines.

\section{The mudstone}

The mudstone is generally dark grey and finely laminated, ranging in grain-size from $\mathrm{Md} 0.002$ $\mathrm{mm}$ to $0.04 \mathrm{~mm}$. Most mudstone boulders are heterolithic with laminae from $1-10 \mathrm{~mm}$ of dark claystone and light grey siltstone (fig. 4). The most fine-grained mudstone consists almost exclusively of illite, with very minor authigenic feldspar, pyrite and carbonaceous matter. With increasing grain-size the amount of detrital quartz increases rapidly, until it constitutes $25 \%$ of the most coarse-grained silty mudstone, which also contains common plagioclase feldspar and biotite flakes as well as framboidal pyrite. Large flakes of carbonaceous matter abound and enhance sedimentary structures such as small-scale 
cross-bedding and convolute lamination (plate 1, fig. D). Silt lenses are common, as are also load and flame structures. A few flute-cast structures have also been observed, as well as small-scale ripples. Limestone concretions, up to $10 \mathrm{~cm}$ thick occur less commonly. In general the lamination is undisturbed, indicating a lack of bioturbation. Beneath the tephra layers the mudstone generally has been strongly silicified to a depth of $6-7 \mathrm{~cm}$.

\section{Graptolite fauna}

In the dark grey mudstone the graptolites are the predominant fossils. In addition, the carbonaceous flakes (see earlier) may possibly also represent organic remains (algae?). A few samples of pyritized triaxone sponge spicules were also observed. Generally the graptolites are flattened, but in some cases they are preserved in relief, infilled with pyrite. Bedding planes with aligned
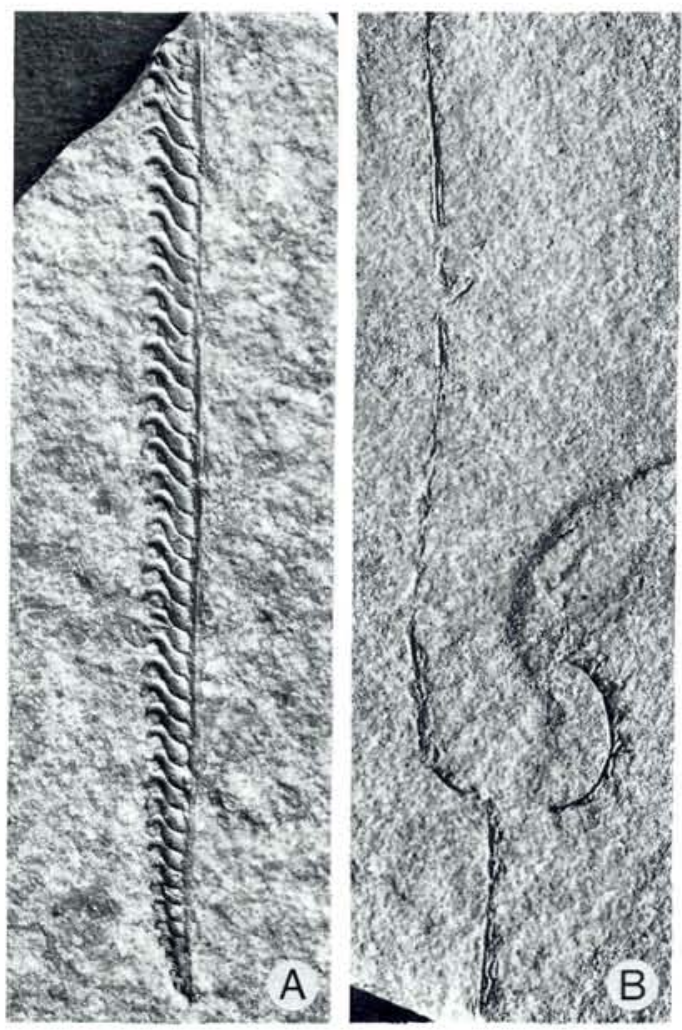

Fig. 5. Graptolites preserved in the dark grey mudstone A. Monograptus flemingi Salter, $\times 2$ 2.5. B. Cyrtograptus hamatus Baily, $\times 3$. rhabdosomes are present, but the great majority of the rhabdosomes are randomly orientated. In some of the coarse-grained mudstone boulders only small fragments and juvenile specimens are found, but in other samples with the same grainsize large slender well preserved cyrtograptids have been seen.

The following graptolite species have been found:

\section{Retiolitid}

Pristiograptus dubius pseudodubius Bouček

Pristiograptus sp. cf. P. meneghini Gortani

Monoclimacis sp.

Monograptus flemingi Salter (fig. 5 A)

?Monograptus irfonensis Elles

Cyrtograptus hamatus Baily (fig. 5 B)

Cyrtograptus perneri Bouček

Cyrtograptus lundgreni Tullberg

?Cyrtograptus urbaneki Teller

Cyrtograptus sp.

The graptolite assemblage indicates the lundgreni Zone, at least its lower part (see below).

In the tuffaceous sandstone $P$. dubius pseudodubias and $M$. flemingi occur in great numbers. Few specimens of Pristiograptus sp. have been seen. In addition, monaxone? sponge spicules, commonly aligned, and a few crinoid ossicles have been observed. In the sandstone the graptolites are generally well preserved in low to full relief as carbon films infilled with pyroclastic grains. Generally, the detailed thecal structures are preserved. In most samples the graptolite rhabdosomes are current orientated, including small fragments, juvenile specimens, and larger rhabdosomes of $M$. flemingi and $P$. dubius pseudodubius.

\section{Stratigraphy}

In the Wenlock Series the international graptolite zonal schemes are based on cyrtograptid and monograptid faunal assemblages and sequences. In the present tuffaceous sandstone the faunal assemblages comprise almost exclusively $M$. flemingi and $P$. dubius pseudodubius, which are the only graptolites determinable to species level. These two species are insufficient to indicate any precise stratigraphic level. $M$. flemingi has been reported from the rigidus to the lundgreni zones, 


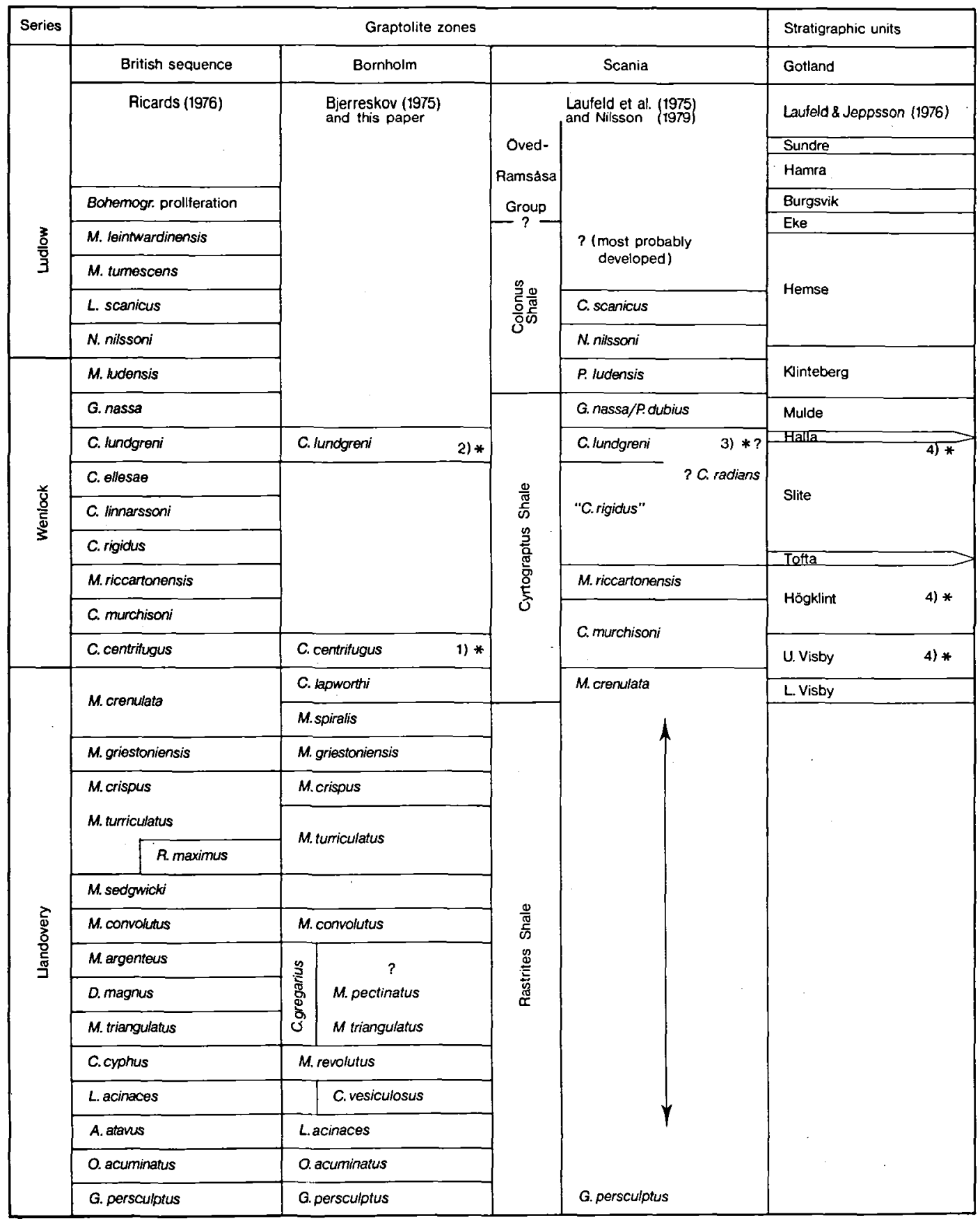

Fig. 6. Schematic diagram showing the Llandovery, Wenlock and Ludlow graptolite zones and stratigraphic units on Bornholm and nearby Swedish areas, Scania and Gotland, compared to the British graptolite zonation. Asterixs nos. 1-4 indicate the stratigraphic position of indicators for Wenlock volcanism. 1. bentonites (Bjerreskov 1975), 2. tuffaceous sandstone, this paper, 3. altered volcanoclastics? (Nyers \& Nilsson 1973), 4. bentonites (Laufeld \& Jeppsson 1976). 
according to the British standard zonation (e.g. Rickards 1976). P. dubius pseudodubius possibly occurs from the rigidus to ellesae zones, and is common in the lundgreni and nassa zones ( $\mathrm{Ri}-$ ckards 1976). In Bohemia the species is reported from the ramosus to testis zones (Přibyl 1943).

In the dark grey mudstone, the presence of $C$. hamatus, which occurs rather commonly, and one specimen of $C$. lundgreni, indicate the lundgreni Zone. In Britain both species occur only in this zone according to Rickards (1976), and in Bohemia $C$. hamatus is restricted to this zone and to the testis Zone (Bouček 1933). In addition, the presence of $M$. irfonensis? and $C$. urbaneki?, both species reported from the lundgreni Zone (Elles \& Wood 1913 and Teller 1976), may confirm the reference to this stratigraphical level. Furthermore, $P$. dubius pseudodubius has its greatest abundance in the lundgreni Zone (Přibyl 1943 and Rickards 1976).

A few specimens of $C$. perneri occur in the dark grey mudstone, and this cyrtograptid is occasionally reported from older graptolite zones. In Britain, C. perneri is present from the flexilis to the lundgreni zones, having peak abundance in the ellesae Zone (Rickards 1976), and in Bohemia it is reported from the flexilis to the radians zones (Bouček 1933). In North America it occurs between the rigidus and lundgreni zones (Berry \& Murphy 1975). P. meneghini has also been reported from older horizons, from the rigidus Zone (Přibyl 1943 and Rickards 1976). The present specimens of $P$. sp. cf. $P$. meneghini have more closely set thecae proximally (10-11 per $10 \mathrm{~mm}$ ) and wider distal parts (up to $2 \mathrm{~mm}$ wide) than measured in $P$. meneghini meneghini by Přibyl (1943), and may represent another stratigraphical level than that of $P$. meneghini meneghini.

$P$. sp. cf. $P$. meneghini and $C$. perneri are associated with a typical lundgreni Zone assemblage. Consequently the older zone, the $e l-$ lesae Zone according to the British sequence, cannot be distinguished as a separate zone. However, the two graptolite species might indicate that at least a number of the boulders originates from the lower part of the lundgreni Zone.

In nearby Scania in southern Sweden the lundgreni Zone has been reported from the Röstånga area (Nilsson 1946) and from the Östra Odarslöv area by Nyers \& Nilsson (1973) and Laufeld et al.
(1975). In Scania the older Wenlock zones, the Elles \& Wood (1901-1918) zones nos. 28-30 in Britain were included in the " $C$. rigidus Zone" according to Laufeld et al. (1975), see fig. 6 .

The lundgreni Zone is a very well recorded zone in Europe and America. In continental Europe it is frequently subdivided (e.g. in Poland) into the subzones of radians and testis (Teller 1969). However, these two subspecies have not been recorded on Bornholm. Thus, on the basis of the present material, a subdivision is not possible, in spite of the fact that the boulders appear to originate from an estimated 20-25 m thick sequence (see below), possibly representing levels yielding different graptolite faunas within the lundgreni Zone. The impoverishment of the graptolite fauna with disappearance of $M$. flemingi and the cyrtograptids, which occurs at the transition to the overlying nassa/dubius interregnum (e.g: Laufeld et al. 1975), has not been observed on Bornholm. There is no evidence of the incoming of shelly faunas as reported from Scania by Laufeld et al. (1975). Accordingly the graptolite assemblage in the boulders on southern Bornholm, indicating a lundgreni zone, with some elements of older graptolites, most likely represents at least a lower part of the lundgreni Zone, with an unknown extension into the upper part.

The upper Wenlock material may represent the stratigraphically uppermost part of the Silurian fault-block which includes the sequence of Llandovery and lower Wenlock mudstone exposed in $\varnothing$ leå (e.g. Bjerreskov 1975). Here, the general strike and dip of the sequence are about $80^{\circ}-90^{\circ} \%$ $4^{\circ}-6^{\circ} \mathrm{S}$ (Bjerreskov 1975). The same orientation of the strata has been measured on mudstone exposed in the seabottom south of Sommerodde. Assuming that the orientation of the beds is rather constant throughout the late Wenlock sequence, which is the case for the Llandovery part of the sequence (Bjerreskov 1975), the late Wenlock deposits can be estimated to be about 20-25 $\mathrm{m}$ thick, comprising the beds in the submarine exposures from a few metres south of the beach and up to a distance of $400 \mathrm{~m}$ off-shore at Sommerodde.

The sequence between the centrifugus and lundgreni zones, which in Scania comprises the murchisoni, riccartonensis and "rigidus" zones (Laufeld et al. 1975) and in Britain the murchi- 
soni, riccartonensis, rigidus, linnarssoni and ellesae zones, (Rickards 1976) has not been observed on Bornholm.

In southern part of Øleå (fig. 1), near the outlet, south of the exposed centrifugus Zone, two EW trending faults were reported by Bjerreskov (1975). Here the exposed beds mainly represented the uppermost Llandovery graptolite zone, the lapworthi Zone. The southern limit of the fault-blocks could not be placed (Bjerreskov 1975). Accordingly the thickness of a possible sequence between the centrifugus and lundgreni zones can here be estimated only very tentatively. The sequence should be situated in the area between Ølea and Stenodde. If it is assumed that the orientation of the presumed strata in the area is around $80^{\circ}-90^{\circ} / 5^{\circ} \mathrm{S}$, as generally measured on the Silurian fault-block sequences, and the two minor fault-blocks terminate just to the south of the outlet of Øleå, the missing sequence may be estimated to be about $15 \mathrm{~m}$ thick. However, additional faults, which have not been registered, might have caused a disappearance of a much thicker sequence. A less likely possibility is that there is a hiatus between the centrifugus and lundgreni zones on Bornholm. Further information is not at present available, as both exposures and wells are too sparse in the area.

The centrifugus Zone on Bornholm is at least about $30 \mathrm{~m}$ thick (Bjerreskov 1975) and the exposed part of the lundgreni Zone is here estimated to be around $25 \mathrm{~m}$ in thickness. The rather uncertain estimated minimum total thickness of about $55 \mathrm{~m}$ for the centrifugus and lundgreni zones on Bornholm can be compared to the 100 $\mathrm{m}$ thickness of the complete "Cyrtograptus Shale" in Scania as assumed by Regnèll in Regnèll \& Hede (1960) and Lindström (1971). The lundgreni Zone in the Östra Odarslöv area is at least 8 m thick (Nyers \& Nilsson 1973).

\section{Taphonomy and ecology}

There is a significant difference between the graptolite faunas in dark grey mudstone and in the light grey tuffaceous sandstone, despite the fact that the two sediment types were deposited contemporaneously. The highest diversity is found in the mudstone comprising at least 11 different graptolite species. In the tuffaceous sandstone only two species are abundant, $P . d u$ bius pseudodubius and $M$. fleming $i$ in addition to a few individuals of Pristiograptus sp. Three models may be proposed to explain this divergence in diversity.

1. The low diversity in the tuffaceous sandstone can have been caused by the physical, chemical or biological destruction of the less robust cyrtograptids and monograptids. These forms possibly had periderms that disintegrated relatively readily, leaving the more robust species such as e.g. $M$. flemingi to be preserved.

However, slender and very well preserved cyrtograptids and diverse slender monograptids are present in the dark grey silty mudstone which locally has a grain-size up to fine sandstone. This demonstrates that even fragile rhabdosomes can be preserved in rather coarse-grained sediments. Futhermore, very delicate graptolite structures are preserved in the tuffaceous sandstone, which has an average grain-size of $0.5 \mathrm{~mm}$, suggesting that extensive destruction has not taken place. Consequently, it should be expected that at least some fragmients of the cyrtograptid and monograptid species were preserved in the tuffaceous sandstone if they had been present in the living graptolite community prior to burial.

2. The living graptolite assemblage was depth distributed as described by Berry and Boucot (1972), who reported a series of late Llandovery graptolite assemblages in correlation with different benthic faunas. Thus the priodon-group occupied the shallowest water depth, the vomerinids were predominating in the next brachiopod community offshore and the cyrtograptids and delicate monograptids were found in the deepest waters. Berry \& Boucot's observations suggest some correspondence to the present observations in the tuffaceous sandstones. The sandstone beds may have been deposited in water over $700 \mathrm{~m}$ deep (see below) by turbidity currents, originating from shallower waters, where $M$. flemingi and $P$. dubius pseudodubius possibly were the two prevalent species. $M$. flemingi is the Wenlock representative of the priodon-group, and $P$. dubius pseudodubius belongs to the dubius types which in the upper part of the Wenlock most likely occupied the same niches as the vomerinids did in late Llandovery. 
3. The third possibility is that $M$. flemingi and $P$. dubius pseudodubius, which are frequently reported in association in upper Wenlock sequences and in various sediment types, originally occupied most niches in the sea water in which graptolites could occur. They were abundant together with the diverse faunas of slender monograptids and cyrtograptids, but they could also thrive and dominate in the outer regions of a community, with possibilities of adaptation that enabled them to live in environments that were stressful for most graptolites. Such stressful environments might include surface layers, shallower waters near shore, and maybe also close to the seabottom. Graptolites having a habitat closer to the bottom could have been killed in the present case by the turbidity currents, maybe as described by Hills \& Thomas (1954), and transported along the bottom, without coming in contact with the graptolite faunas living nearer to the water surface. An equivalent graptolite assemblage, dominated by priodon-flemingi types and containing few pristiograptids, has been descri- bed from late Llandovery and Wenlock flysch sequences in North Greenland (Bjerreskov in press), deposited in a deep trough after longitudinal transportation (e.g. Surlyk et al. 1980).

In conclusion, the divergence in the diversity of the graptolite faunas in the present two types of sediment may provide evidence of differentiation in the spatial distribution of species in living graptolite faunas. Erdtmann (1976) discussed similar patterns for Ordovician graptolite faunas. Dissimilar but coeval graptolite associations have also been recorded for late Silurian faunas by Watkins \& Berry (1977) and for Middle Ordovician graptolites by Berry (1977). In both studies the distribution patterns were correlated with basin and shelf waters and compared with the present day oceanic plankton communities, where certain fauna associations are restricted to water masses having specific hydrographic characteristics.

At present it cannot be concluded precisely in which water masses the flemingi/dubius pseudodubius fauna dominated in life. However, it is

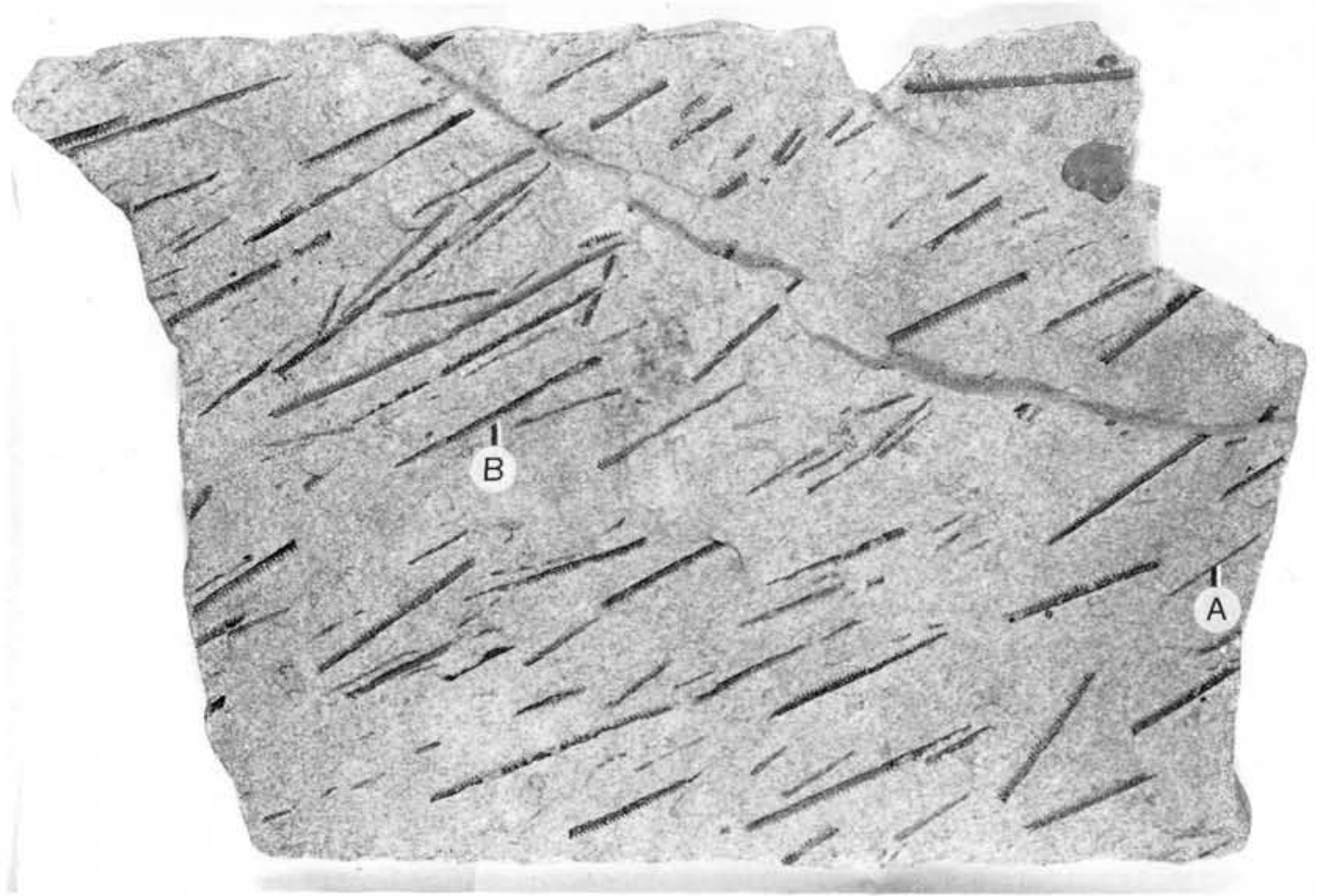

Fig. 7. Slab of the ash-turbidite showing aligned rhabdosomes of $P$. dubius pseudodubius (A) and M. flemingi (B). Length of slab 32 $\mathrm{cm}$. 
suggested that the two species, apparently possessing an adaptation that enabled them to survive in more shallow waters on shelf areas, cf. Berry \& Boucot (1972), also may have had the ability to occupy a niche closer to the seabottom than other contemporaneous graptolite species.

The tuffaceous sandstone boulders are generally rather small, with bedding planes less than $100 \mathrm{~cm}^{2}$, allowing only few graptolite rhabdosomes to be measured for size-frequency analyses. However, one larger ash-turbidite boulder (fig. 7) has been investigated. On the surface there are more than 50 aligned specimens of $M$. flemingi and $P$. dubius pseudodubius on a single bedding plane. The orientation and corresponding size-frequency histograms of these are indicated in fig. 8, A1-C2.

As the slab was loose material, the original direction of the aligned rhabdosomes has been lost, and the orientation of the rhabdosomes is meas- ured in relation to the dominant joint direction. In the diagrams the proximal-distal orientation of the rhabdosomes is plotted.

Fig. 8, Bl, C1 shows that about $2 / 3$ of the $M$. flemingi and the majority of the $P$. dubius pseudodubius rhabdosomes lie with their proximal ends pointing in the same direction with $20^{\circ}-$ $30^{\circ}$ deviation. This is in contrast to results presented by Rickards (1975) for current orientated graptolites. He described one direction for the flemingi specimens and the opposite direction of the dubius rhabdosomes. The lack of this kind of sorting in the present case might be due to the rapid deposition of the tuffaceous sandstone. The size-frequency diagrams for $M$. flemingi rhabdosomes with opposite directions (fig. 8, B3, B4) show a small and indistinct size difference between the two groups, but unfortunately the material is quantitatively too small for significant conclusions.
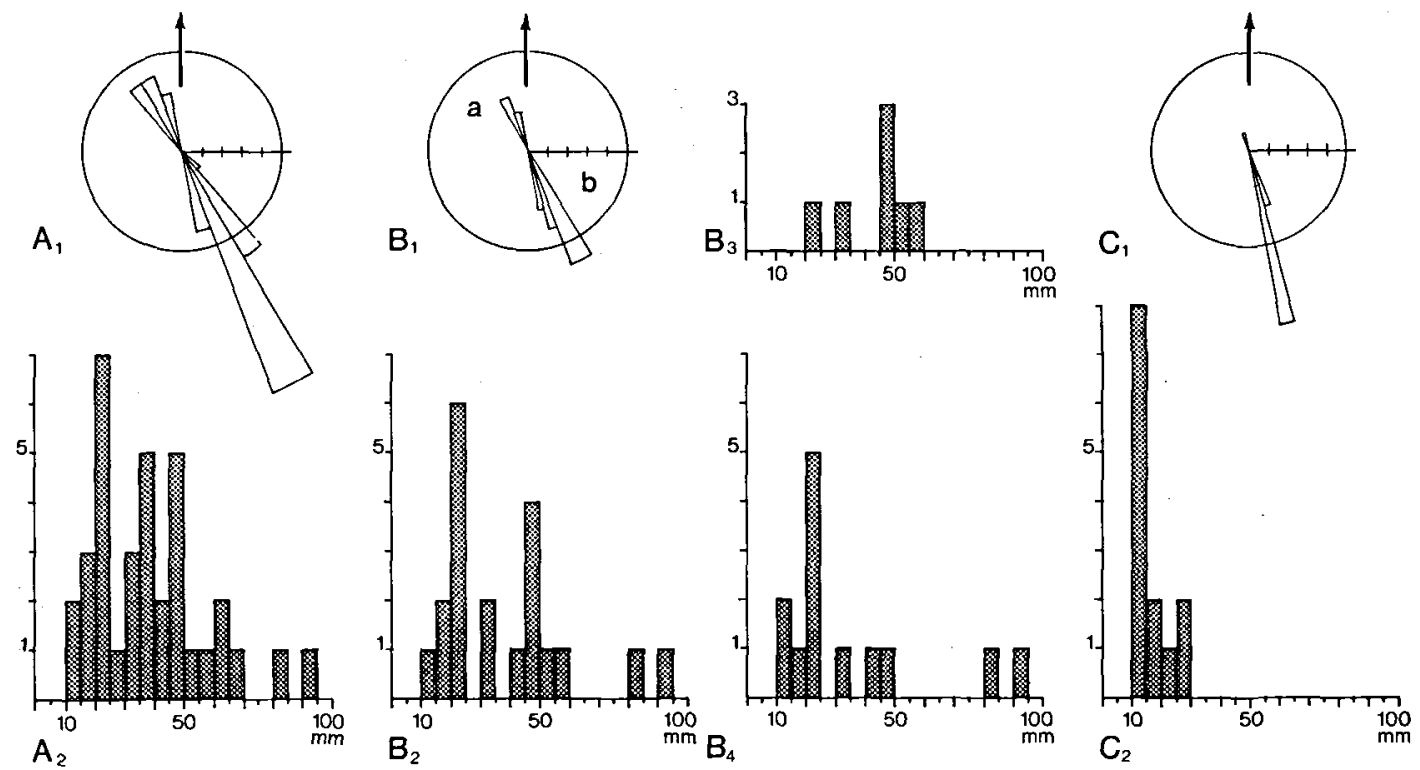

Fig. 8. $\mathrm{A}_{1}-\mathrm{C}_{2}$. Rosette diagrams and size-frequency histograms based on measurements of the $M$. flemingi and $P$. dubius pseudodubius rhabdosomes on the slab shown in fig. 7. Circle indicates 5 specimens and is divided into $10^{\circ}$ classes. Arrowed line indicates the dominant joint direction. Proximal rhabdosomal parts are directed away from the centre of the circle. Vertical scale in the histograms gives the number of specimens, and lengths of rhabdosomes are given by the horizontal scale in mm.

The class interval is $5 \mathrm{~mm}$.

$\mathrm{A}_{1}$ : Rosette showing the orientation of all $M$. flemingi rhabdosomes, including distal fragments $(\mathrm{n}=35)$.

$\mathrm{A}_{2}$ : Histogram corresponding to $\mathrm{A}_{1}$ showing the size-frequency of all $M$. flemingi rhabdosomes.

$\mathrm{B}_{1}$ : Rosette showing the orientation of $M$. flemingi habdosomes retaining both the slender part and sicula $(\mathrm{n}=20)$.

$\mathrm{B}_{2}$ : Histogram corresponding to $\mathrm{B}_{1}$.

$B_{3}$ : Histogram showing size-frequency of the $M$. flemingi rhabdosomes with orientation in the a part of $B_{1}(n=7)$.

$\mathrm{B}_{4}$ : Histogram showing the $M$. flemingi rhabdosomes with orientation in the $b$ part of $\mathrm{B}_{1}(n=13)$.

$\mathrm{C}_{1}$ : Rosette showing the orientation of all $P$. dubius pseudodubius rhabdosomes comprising 10 specimens with proximal slender part and sicula, plus 3 specimens lacking sicula.

$\mathrm{C}_{2}$ : Histogram showing the size-frequency of the 13 specimens of $P$. dubius pseudodubius. 
The alignment of the rhabdosomes is in a single direction (fig. 8, $\mathrm{A}_{1}, \mathrm{C}_{1}$ ) producing unimodal rosettes. The rhabdosomes were apparently deposited with the long axis parallel to the current direction, "a" direction, as the specimens lie parallel with sole mark structures on the basal surface of the same slab. This is in agreement with observations of Schleiger $(1968,1969)$ who described a correlation between sedimentary current-generated structures and graptolite alignment. The faunal alignment does not represent polymodal populations sorted by current actions as earlier described for graptolites in turbidites (Moors 1969).

The histograms (fig. 8, $\mathrm{A}_{2}, \mathrm{C}_{2}$ ) indicate that juvenile specimens and/or small proximal fragments with lengths less than $1 \mathrm{~cm}$ are totally absent both among the $M$. flemingi and $P$. dubius pseudodubius specimens. Possibly the juvenile specimens lived in a different place from the adult graptolite fauna, or the small specimens may have been destroyed; or again, they may have been selectively removed by current action owing to their small mass. In addition, all factors could have contributed together for the present lack of specimens less than $1 \mathrm{~cm}$ in length.

The histograms (fig. 8, $\mathrm{A}_{2}, \mathrm{C}_{2}$ ) do not show the normal bell shape for a well sorted fossil population, but are left skewed, or in some cases have more than one peak (fig. $8, \mathrm{~B}_{2}$ ).

The left skewed histograms may be explained by taphonomic processes causing an underrepresentation of larger specimens. There may have been some sorting by current action and the rhabdosomes might have been broken before deposition. This would give the impression of a fauna with dominance of juveniles instead of a well sorted death assemblage, deposited without damage after transport over a long distance. Furthermore, the broken fragments at the edges of the slab have not been measured, and the total graptolite fauna preserved on the slab must have included a few longer rhabdosomes than are indicated in the histograms.

However, in the present case it is also possible that the turbidity currents have killed and rapidly buried a living graptolite assemblage having a dominance of young colonies. It is even possible that the two maxima in the histogram $B_{2}$ might represent two generations. The present material is, however, far too small for any safe conclusion to be drawn on this point. The slab might represent a very rapidly buried graptolite life assemblage. This would be a very special case in graptolite fossilization, preserving more or less the original, total graptolite assemblage, since graptolite assemblages normally originate from accumulations of dead rhabdosomes, transported, selectively destroyed and sorted before final burial.

Consequently, with the present very limited material, it cannot be safely concluded from the size-frequency histograms whether the assemblage on the tuffaceous sandstone slab has been affected by taphonomic processes or whether it is a rare case of a "frozen" life assemblage dominated by young colonies.

\section{Silurian volcanic activity in neighbouring areas}

Reports of Silurian volcanic activity in Denmark are few. From the Silurian exposures on Bornholm, comprising the Llandovery and only the lowermost Wenlock, about 20 bentonite layers have been reported by Bjerreskov (1975). In addition at least 10 rusty thin layers have been found, possibly representing weathered bentonite layers. However, as only about half of the sequence is exposed, the total number of bentonite beds may be estimated to be about $50-60$ for the Llandovery Series.

In the deep wells at Rønde and Nøvling, Ludlow strata, including lower Ludlow, have been penetrated (Rasmussen et al. 1971 and 1973), comprising mainly redbrown claystones with subordinate sandstones and limestones. Colonograptus colonus (Barrande) was reported from the lower part of the Nøvling boring (Christensen 1971) and shelly faunas are present in the upper Ludlow parts in both Rønde and Nøvling. Within the Ludlow sediments, three sequences of igneous formations (basalts) have been found above the claystone with $C$. colonus. At least the uppermost parts have been considered to be extrusive, and the overlying sediments appear to be weathering products of these (Christensen 1971). The volcanics from the Nøvling boring were dated by Larsen (1971), who arrived at an age of $276 \pm 12$ mill. years, i.e. Permian; however, this date was interpreted as indicating that the vol- 
canics had lost the radiogenic argon in the Permian.

The occurrence of bentonites in the Silurian (and Ordovician) sequences in other parts of Scandinavia was first described by Thorslund (1945). Later (1948a and 1948b) Thorslund reported bentonites and tuffs from Jämtland and Gotland, in Llandovery sequences. From the Llandovery strata in Kinnekulle, Wærn (1948) mentioned 7 bentonite beds. In 1960 Waern reported 40 bentonite layers from the Llandovery in Dalarne, the number corresponding closely to the estimated $50-60$ beds on Bornholm for nearly the same sequence. In Sweden, reports of volcanism from Wenlock strata are sparse. From Scania, no definite descriptions of beds of volcanic origin from the uppermost parts of the "Cyrtograptus Shale" have been made. However, Nyers \& Nilsson (1973, figs. 3, 6) showed in the core No. 2 from the lundgreni Zone in Östra Odarslöv a few layers of silicified shales directly overlain by either vein calcite or loss of core. These silicifications might have been caused by overlying bentonite or other volcanoclastic beds. Alteration of the volcanic sediments through weathering may have entirely removed the rocks or caused their replacement by the vein calcite, thereby weakening the shale sequence and causing the loss of core material.

Laufeld \& Jeppsson (1976) reported several bentonites throughout the Wenlock and Ludlow sequence on Gotland. Here the beds directly underlying the bentonites are silicified. It may be significant that in the lowermost part of the lundgreni Zone, in the Slite Marl, 4 bentonite beds have been observed. However, more detailed investigations are needed to demonstrate whether the bentonite beds on Gotland originate from the same 4 eruptions as those indicated by the tuffaceous sandstone on Bornholm.

Within the Oslo region in Norway at least 7 different Silurian bentonite beds have been reported by Hagemann (1966). However, here the bentonites all occur in the lower part of Stage $7 \mathrm{c}$ in the Late Llandovery.

In neighbouring countries outside Scandinavia several volcanic events of Wenlock age are known. Jürgenson (1964) reported a total of 51 Silurian bentonite layers from Estonia, although they are mainly from the Adavere and Jaani
Stages, comprising the sedgwicki to ellesae Zones (e.g. Kaljo \& Jürgenson 1977).

From Latvia, Ulst (1968, fig. 3) demonstrated Wenlock bentonites, comprising 3 beds from the flexilis Zone to the lundgreni Subzone. From Podolia, Nikiforova \& Predtechensky (1968) reported one $30 \mathrm{~cm}$ thick bentonite layer from the Wenlock Ustje beds.

To the south of Denmark, in the Barrandian, Horny (1960) reported intense volcanism at the end of Wenlock, and from Frankenwald, Greiling (1958) described effusive volcanic activity in the Silurian, with greatest intensity in the late Llandovery and late Wenlock to early Ludlow.

From Poland, tuffaceous material has been reported from the upper Llandovery in the Lutom 1 borehole (Tomczyk 1962), and the presence of lower Ludlow bentonites and tuffs was mentioned in Tomczyk (1970).

\section{Discussions}

\section{Depositional environment}

Throughout the early Palaeozoic Bornholm was situated within the Fennoscandian - East-European platform, and the Lower Palaeozoic sequence reflects periods of increasing sea-depth and transgressions alternating with progradations or aggradations. To the south of Bornholm and the Ringkøbing-Fyn High, across Rügen and the northwestern part of Poland lies an E-W branch of Caledonian foldbelt. According to Dadlez (1974, fig. 2) and Ziegler (1978, fig. 2, 1981, fig. 4) the presumed SW border of the Fennoscandian craton is situated about $50 \mathrm{~km}$ south of Bornholm in the Baltic Sea. The thick early $\mathrm{Pa}$ laeozoic platform series in Scania, around Bornholm and in Poland, now lies in the foreland of the North German-Polish Caledonides (Ziegler, 1981).

At the beginning of the Silurian there is evidence of a transgression on Bornholm, most likely representing the world wide eustatic rise following the late Ordovician glaciation, e.g. Berry \& Wilde (1978). Throughout the Llandovery and lowermost Wenlock, $160 \mathrm{~m}$ mainly dark grey mudstones were deposited, generally under anoxic conditions (Bjerreskov 1975). The upper 
Wenlock lundgreni Zone, at least the lower part of the zone, is estimated here to be about 20-25 $\mathrm{m}$ thick. In this zone the deposits are dark grey mudstone, generally containing more silt than that of the older Silurian deposits on Bornholm. The prevailing bottom conditions most likely also were anoxic, as generally no traces of benthic aerobic life have been recorded, indicating an oxygen concentration of less than $0.3 \mathrm{ml} / \mathrm{l}$ (Rhoads \& Moorse 1971). Apparently the strata are more coarse-grained than the shales from the corresponding stratigraphical level in the nearby Scanian sequence (Laufeld et al. 1975).

In the Ludlow the Bornholm area was located centrally within an intracratonic basin - named the Oslo-Scandian Baltic syneclise by Størmer (1967). This basin underwent rapid subsidence, as up to $2 \mathrm{~km}$ of deposits have been recorded in the Leba boring in North Poland, while in Scania the Ludlow and Pridoli deposits, the Colonus Shale and the Öved Ramsåsa Group together attain a thickness of about 900-1400 m (Regnèll 1960). Further seismic evidence of some kilometre thick (Lower) Palaeozoic sediments in the Skagerrak, North Jylland, Kattegat and Sjælland regions has been reported by Michelsen \& Andersen (1981). Most likely these sequences include thick Silurian deposits. Ludlow deposits corresponding to the Colonus Shale have neither been recorded in deep borings nor with certainty in exposures on Bornholm (Laursen 1943, Rosenkrantz 1944), but they may occur in the Baltic Sea surrounding Bornholm, specially to the south and east (Poulsen 1966).

The late Wenlock Bornholm mudstone locally somewhat resembles, both in lithology and sedimentary structures, the Scanian Colonus Shale. Within this shale a transport of the sediment in an W-NW to S-SE direction has been observed by Lindström (1960), and he suggested a longitudinal transport of material within the basin. In the Bornholm material the scour marks and the alignment of the graptolites indicate nearly the same palaeocurrent direction in all the measured samples, forming an angle of about $20^{\circ}-30^{\circ}$ to the dominant joint direction which is observed to be $\mathrm{N}-\mathrm{S}$. However, no further information is available on the direction of the transport of the late Wenlock deposits on Bornholm.

In the thick Ludlow deposits in the western part of Poland, Jaworowski (1971) found indica- tions of a transport mainly from SW-NE, transversally into the Ludlow basin. He indicated that a source land area for the Ludlow sediments in Poland was possibly situated towards the west, around Rügen, and maybe also in the southern part of Denmark. Lindström (1960) suggested that the source of the deposits of the Colonus Shale was an elevated area around Slagelse. These suggestions have been further supported by a brief reinvestigation of the Silurian deposits in the Slagelse boring by M. Bjerreskov. In the cores nos. 7-8, depths $2637 \mathrm{~m}-2644 \mathrm{~m}$, referred to the crispus Zone by Poulsen (1974), micaceous sandstone were found containing graptolites of the dendroid and priodon types, possibly indicating uppermost Llandovery to lower Wenlock age. The sediment and graptolite assemblage suggest a prograding sequence, probably caused by an elevation of the area concerned.

According to Tomczyk \& Tomczykowa (1978, fig. 3), the northern border of the microcontinent, the East Elbe massif, was situated around Slagelse in late Wenlock and continued further towards SE into the western part of Poland. This microcontinent could have been, at least in part, the source area for the Wenlock-Ludlow deposits in the "Baltic Syneclise". Furthermore, Tomczyk \& Tomczykowa (1978) described a rapidly subsiding platform in the north-east shelf of the Protothetys, within a marked period of unrest in the upper Wenlock and at the Wenlock-Ludlow boundary, causing lithofacial changes in Poland. The accelerating subsidence of the platform was documented by a $300 \mathrm{~m}$ thick testis Zone in the Slupsk Boring in Northern Poland. They further suggested an increase in volcanism in connection with the period of unrest, especially in the Barrandian (also reported by Horny in 1960, see above). It would seem that Bornholm within this period of increased subsidence was also situated in a rather mobile part on the outer edge of the Precambrian platform, and the late Wenlock sequence was deposited in a basin having a depth of $1000 \pm 300 \mathrm{~m}$ (see later).

\section{Origin of the tuffaceous sandstone}

The clast-bearing bed was undoubtedly deposited from some kind of gravity flow as indicated by the cyclic units, the marked current orientation, the 
scour marks and flute casts, the imbrication of the substrate as well as the large grain-size and poor degree of sorting.

Middleton \& Hampton (1973) listed 4 different sediment-support mechanisms: 1) turbulence supported (turbidity currents), 2) upward flow of fluid supported, 3) grain to grain interaction supported, and 4) matrix supported; however, they also stated that most deposits will have a hybrid character. The present case shows evidence of turbulence in the lower part of the deposit, as indicated by the scour marks and the randomly distributed graptolite fragments. However, the current orientated graptolites and clasts are indicative of a laminar flow-regime. The similarity of the clasts to the underlying mudstone, precludes long-distance movement of these, although the abrasion of some of the clasts indicates that they must have either been transported for some distance or were not indurated. The relationship shows that the flow was mostly fluid and turbulence supported. The short distance travelled by the larger clasts is thus in accordance with the calculations on liquefied flows by Lowe (1976, fig. 3).

In general the features discussed appear to indicate deposition in the distal part of a turbidite sequence as outlined by Walker (1967), and this is further confirmed by the distinctive silty mudstone described, which has much in common with the thin-bedded turbidites described by Mutti (1977), especially his lobe-fringe facies.

The origin of the ash-turbidite, however, also presents problems. At least three depositional models can be considered. 1) deposition in the distal part of a subaquatic pyroclastic flow, whether erupted subaerially as described by Sigurdsson et al. (1980) or subaquatically as described by Fiske (1963), 2) deposition from a turbidite developed by sector collapse of a growing volcanic dome (as can be observed in the Moberg Formation of Iceland (K. A. Jørgensen unpublished observation)), and 3) deposition from a turbidite from slumping of a mechanically unstable tephra layer settling on a palaeoslope, and possibly triggered by syneruptive earthquakes, as described by Huang (1980).

The first possibility is considered unlikely owing to the general lack of large pumices and the very low xenolithic content. The second type would be characterized by abundant angular

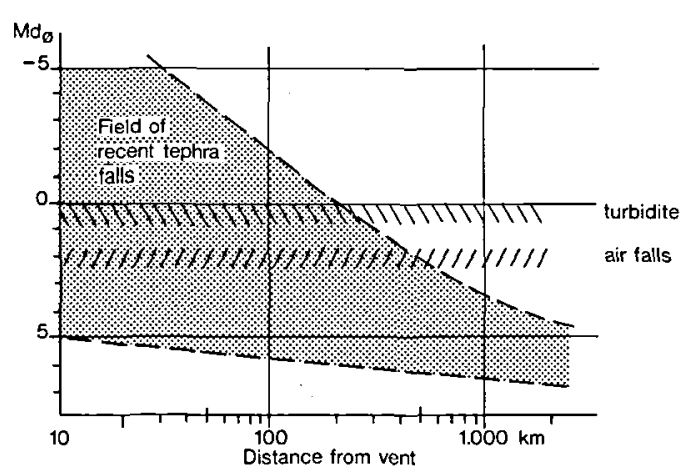

Fig. 9. Diagram showing median grain-size (Md $\varnothing)$ against distance to source, showing field of air-fall tuffs from Walker (1971) with additions from Ninkovich et al. (1978), and the grain-size ranges for the tuffaceous sandstone from Bornholm.

fragments, more or less crystalline (K. A. Jørgensen, unpublished observation), which certainly do not occur in this case. The third possibility, however, would produce a deposit like the one described, at least in the distal part of the turbidite.

The origin of the non-clast bearing beds is more straightforward as they show every evidence of being waterdeposited ash-fall beds, although the laminated beds could be interpreted as part of a "Bouma sequence" (Bouma 1962), and thus parts of turbidites. The impacting crystals into the underlying clay, the concentration of heavy minerals and massive shards in the bottom part of the layer, the constant size of the largest feldspar fragments throughout most of a bed with a sudden decrease in size towards the top, and especially the lack of scour marks, convolute lamination and stream-orientation, are all features favouring a water-sorted ash-fall origin (Ledbetter \& Sparks 1979).

If the observed grain-sizes are compared with those of modern ash-falls (Walker 1971, Ninkovich et al. 1978), a maximum distance to source in the order of $300 \mathrm{~km}$ is obtained. This figure, however, is only valid along the fall-axis (fig. 9). A deviation from the main axis will result in a somewhat smaller figure. The laminations in the layers implies pulses in the rate of deposition. This pulsation must result from pulsations in the eruptive column, or from changes in the meteorological conditions. These shifts can only occur at low altitude, as the wind speeds and directions in the troposphere generally penetrated by 


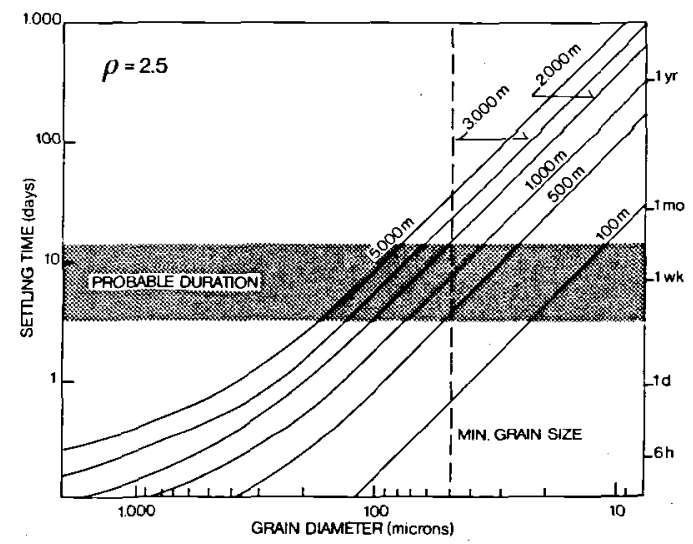

Fig. 10. Settling velocity diagram for feldspars (density $p=2.5$ ) adopted from Ledbetter \& Sparks (1979), with inserted presumed duration and smallest grain-size of feldspar found in the thickest laminated bed.

plinian eruptions are fairly constant. The regular occurrence of the laminations at the very bottom of the layer seems to exclude the possibility of pulsations within the eruptive column, as plinian eruptions generally are characterized by an initial phase of continuous uprush, resulting in rather homogeneous deposits for the lower part, followed by stratified beds in the upper part, resulting from intermittent activity in the later stages of the eruption (Walker \& Croasdale, 1972). Changes due to shifts in meteorological conditions will generally only be discernible in the fringe of the fall-out area, and thus it can be speculated that the laminated deposits formed in the peripheral parts of ash-fall areas. The origin of these cyclic variations could be due to the passage of frontal cyclones, but considering the probably equatorial palaeoposition of the area (Smith et al. 1981), and the simple fact that frontal cyclones commonly only occur once a week, giving an unrealistically high duration for the eruption, thus must be discarded. A more tenable idea is that the cyclicity could be due to diurnal variation commonly observed in coastal areas. The number of laminations observed in the thickest deposit is 5 to 6 (fig. 3), implying an eruption duration of about a week. The rest of the deposit then represents later deposited material, with the grainsize increase towards the top being due to sinking of late waterlogged pumices, floating around after the eruption. Using the maximum (300 microns) and minimum (50 microns) sizes for the presumed discrete feldspar crystals, and a presumed eruption duration of a week in the Ledbetter \& Sparks (1979) sinking model fig. 10, gives a water depth estimate of $1000 \pm 300 \mathrm{~m}$. Taking into consideration more conservative estimates (e.g. Ziegler 1981) that imply that the area had rather shallow waters at the time in question (see earlier) the figure is unexpectedly high, but as the main problem is the sinking time for a particle of a given size and density, the figure is realistic. Even if one could accept the highly improbable situation that the eruption was over in a day, the depth of settling would be in the order of $200 \mathrm{~m}$.

The grain-size distribution in the ash-turbidite must also have some significance as it was generated from air-fall ash. The material constituting the turbidite must be an integration of the material available between the place of initiation and the present site minus the resedimented material. Thus the median grain-size of the turbidite is a function of the distance from the eruption site to the place of turbidite initiation, at the most 200 $\mathrm{km}$.

The observed shard and lapilli types are those of normally vesiculated, subaerially erupted silicic tuffs, except for the layer with the massive shards which must have formed in a phreatoplinian phase (a plinian eruption in shallow water) (Heikeh 1974).

The mineralogy of the layers is typical of those from high-silica, voluminous asheruptions such as those found in western U.S.A. (Hildreth 1979), New Zealand (Ewart et al. 1975), Japan (Ui 1971) and similar places (Aleutians, Indonesia, Kamchatka, Iran, Turkey). The dominance of the $\mathrm{K}$-rich minerals biotite and sanidine, is unusual for most of the magmatic provinces referred to. However, in the western U.S.A. (Hildreth 1979) there are rhyolites having similar mineralogy, and so have recent rhyolites from Turkey (Keller \& Villari 1972). Both places are old continental areas dominated by large-scale transcurrent faulting and associated fracturing, similar to the situation suggested by Brochwicz-Lewinski et al. (1981), see below.

\section{Source of volcanism}

The above mentioned late Wenlock increase in 
volcanism on Bornholm is indicated by the presence of the tuffaceous sandstone. The intensity of volcanism at that time is most likely also shown by the four bentonite beds.in the Slite Marl in the transition ellesae-lundgreni zones on Gotland (Laufeld \& Jeppsson 1976) and can possibly also be traced within the lundgreni Zone in Scania (see above).

The position of the volcanoes that produced the numerous bentonite beds both in Ordovician and Silurian in Scandinavia has been discussed several times. The classical suggestion was an origin from volcanoes in the Caledonian geosyncline along NW Norway (e.g. Magnusson et al. 1963), but recently Laufeld \& Jeppsson (1976) suggested that the late Llandovery to lower Ludlow volcanoes were situated south of Scandinavia, maybe in the Barrandian. In addition, the Ordovician bentonites from Kinnekulle in Vestergötland are dissimilar to those in the Norwegian Caledonian mountains (Bergström 1956). The Wenlock tuffaceous sandstone on Bornholm originates from acid continental volcanoes, and has no relationship with the basaltic eruptions recorded in the Ludlow deposits in the deep borings at Rønde and Nøvling in Middle Jylland.

On the basis of the palaeocontinental world maps in Smith et al. (1981) the Ludlow palaeoequator was apparently situated north of the Bornholm area, which possibly had a palaeolatitude of around $10^{\circ} \mathrm{S}$. If it is assumed that the Silurian wind systems were of about the same configurations as today, the SE trade winds might possibly have transported the airborne volcanic ashes towards north. Accordingly, it is here suggested that the plinian eruptions might have originated south of Bornholm. An eruption centre at a maximum distance of about $300 \mathrm{~km}$ from Bornholm (see above) could thus correspond to a position in northern Germany or northern Poland. The position appears to correspond to the southern part of the East Elbe massif, according to the extent indicated by Tomczyk \& Tomczykowa (1978, fig. 3). This microcontinent might later have disappeared within the Caledonian foldbelt, leaving no trace of the original volcanoes. On the other hand, however, the volcanoes might have been obliterated by the large-scale Lower Palaeozoic strike-slip movements along the SW margin of the East-Euro- pean platform which were suggested by Brochwicz-Lewiǹski et al. (1981).

If the latter theory is accepted, then the Wenlock volcanoes would have been dislocated in a direction towards the Black Sea and, if they survive, will now lie in SE Europe, south-west of but close to the Tornquist-Teisseyre line.

\section{Conclusions and summary}

The present investigation of the late Wenlock dark grey mudstone and tuffaceous sandstone, mainly occurring as boulders on the eastern part of the south coast of Bornholm, has led to the following results and suggestions.

1. According to the geological setting of the area, the boulders may have originated from a sequence having an estimated thickness of about 25 $\mathrm{m}$. The graptolites of the dark grey mudstone indicate the Cyrtograptus lundgreni Zone, at least the lower part of the zone. The tuffaceous sandstone samples represent at least 3 airfall water deposited tuff beds and one bed deposited by turbidity current action.

2. The taphonomical and ecological aspects of the difference in diversity of the graptolite faunas in the dark grey mudstone (comprising 13 species) and the tuffaceous sandstone (only two species, $M$. flemingi and P. dubius pseudodubius), are discussed. It is suggested that the latter two species were more common, not only in the lower levels of the water column, but also maybe living closer to the seabottom than other coexisting graptolite species. Size-frequencey analysis of aligned $M$. flemingi and $P$. dubius pseudodubius rhabdosomes in a slab of tuffaceous sandstone has not led to safe conclusions as to whether the assemblage represents a rare case of a preserved graptolite life assemblage, dominated by young individuals and rapidly buried by the volcanic ash turbidite, or alternatively whether the original assemblage has been adjusted by various taphonomical processes before final imbedding.

3. The mudstone and tuffaceous sandstone are deposited within a basin, "the Baltic Syneclise", close to the SW margin of the Fennoscandian 
platform in the foreland of the North GermanPolish Caledonian foldbelt. Evidence from the airfall water deposited tuff beds suggests that the basin depth was $1000 \mathrm{~m} \pm 300 \mathrm{~m}$. Generally the bottom conditions were anoxic. The mudstone may represents distal turbidites, but the direction of transport cannot be finally proved. There are som lines of evidence that the terrigenous material migth derive from an elevated area, possibly a microcontinent, the East Elbe massif, situated in the southern part of Denmark and in N. Germany and N. Poland (Lindström 1960, Javorowski 1971, Tomczyk \& Tomczykowa 1978 and herein).

4. The primary mineral composition in the tuffaceous sandstone comprises sanidine, plagioclase, quartz, biotite, amphibole, pyroxene?, Fe-Ti oxides?, zircon, and apatite. The K-minerals indicate a continental origin for the volcano. Grainsize analysis suggests that the eruption centre was placed at a maximum distance of $300 \mathrm{~km}$ from Bornholm. It is assumed that, in Wenlock, Bornholm had a position of $10^{\circ} \mathrm{S}$ latitude, maybe within the SE trade wind belt, causing transport of the volcanic ashes from the south, corresponding to a position of the volcanic centre in or near to the East Elbe massif. Evidence of increased volcanic activity in late Wenlock have been further noted by Horny (1960) in Barrandian, by Tomczyk \& Tomczykowa (1978) in Poland and on Gotland by Laufeld \& Jeppsson (1976).

\section{It is here proposed that the late Wenlock vol-} canic eruption centres, supposedly lying SW of the margin of the East-European platform, later, in uppermost Silurian or Lower Devonian, either disappeared within the Caledonian foldbelt or were displaced towards SE by a large scale strikeslip fault along the Tornquist-Teisseyre Line zone.

Acknowledgements. The authors have discussed various aspects of the present investigation with many colleagues, who are thanked for inspiration and valuable comments. B. Hageskov is thanked for the first analyses of the thin sections. The Danish Science National Research Council is thanked for providing microprobe facilities under supervision of J. Rønsbo. R. Bromley kindly improved the English text. J. Aagaard made the photographs, H. Egelund drew the figures and tables, I. Nyegaard made the plate and $\mathrm{E}$. Møller-Hansen typed the manuscript.

\section{Dansk sammendrag}

Øvre Wenlock mørkegrå ler- og siltsten (skifre) samt tuffitiske sandsten er fundet som løse blokke på stranden på Bornholms østlige sydkyst. Faststående ler- og siltsten af samme alder er desuden observeret $i$ havet op til ca. $400 \mathrm{~m}$ ud for kysten. Her er lagenes orientering $80-90 / 4-6^{\circ} \mathrm{S}$, og muligvis repræsenterer det samlede materiale en $25 \mathrm{~m}$ tyk sekvens. Skiferens graptolitfauna, ialt omfattende 13 arter, indicerer Cyrtograptus lundgreni Zonen, som er korreleret med øvre Wenlock sektioner $i$ andre dele af N. Europa, bl.a. i Skåne. $P$. dubius pseudodubius og $M$. flemingi er stort set de eneste graptolitarter observeret $\mathrm{i}$ tufsandstenen, som til dels er afsat som turbiditer. De taphonomiske og $ø$ kologiske aspekter af diversitetsforskellen i de to sedimenttyper er diskuteret, de to sidstnavnte graptolitarter har muligvis, ud over at være dominerende på lavt vand, også været de almindeligste graptoliter nær havbunden. Size-frequency analyse af strømorienterede eksemplarer af de to arter $i$ en turbiditisk tufsandstensblok har ikke definitivt kunnet påvise, om faunaen reprasenterer et for graptoliter meget sjældent bevaret fossilt livssamfund, domineret af unge individer, eller om faunaen har været udsat for påvirkning af forskellige taphonomiske processer.

Tufsandstenen består af omdannet vulkansk aske, med velbevarede texturer. Den primære mineralogi har været sanidin plagioklas, kvarts, biotit, amfibol, pyroxen?, Fe-Ti-oxider?, zirkon og apatit, men er nu stærkt omdannet. Dominansen af $\mathrm{K}$-mineraler antyder en kontinental oprindelse. Der er observeret to aflejringstyper, en graptolitførende turbidittype med rip-up klaster af den mørkegrå ler-siltsten samt en lamineret askefalds type. Kornstorrelsesanalyser antyder en maximum afstand til udbrudscentret på $300 \mathrm{~km}$ samt en sedimentationsdybde på $1000 \mathrm{~m} \pm 300 \mathrm{~m}$. Sedimenterne er generelt afsat under anoxiske forhold $\mathrm{i}$ et bassin inden for den "baltiske syneklise", nær randen af den fennoskandiske platform, $i$ forlandsbæltet for de nordtyske og polske caledonider. Strømretningen $\mathrm{i}$ bassinet kan ikke her definitivt angives, men tidligere arbejder samt fornyede undersøgelser indicerer, at det terrigene materiale kunne stamme fra et højereliggende område, måske det $\emptyset$ st-Elbiske mikrokontinent, med antaget udstrækning over Syddanmark, Nordtyskland og det nordlige Polen. Bornholms palæoposition i Wenlock har antagelig været omkring $10^{\circ} \mathrm{S}$ bredde, måske $i$ et daværende $S \emptyset$ passatbælte, hvis vinde har forårsaget en transport af vulkansk aske fra syd mod nord. Vulkanernes udbrudscenter kan derfor muligvis placeres syd for Bornholm, nær eller i det Øst-Elbiske mikrokontinent i Nordtyskland eller NV-Polen, sydvest for Tornquist-Teisseyre Linien. De oprindelige vulkaner kan være forsvundet under den caledoniske foldning. Ifølge den nyligt fremsatte teori om Nedre Palzozoisk storskala sideværts forkastninger hen over Syddanmark og langs Tornquist-Teisseyre Linien, kunne det måske også tænkes, at vulkancentrene senere var dislocerede mod SØ-Europa langs Tornqust-Teisseyre Linien.

\section{References}

Berry, W. B. N. 1977: Ecology and age of graptolites from graywackes in eastern New York. J. Paleontol. 51: 11021107.

Berry, W. B. N. \& Boucot, A. J. 1972: Silurian graptolite depth zonation, 24th Int. Geol. Congr. Sect. 7: 59-65.

Berry, W. B. N. \& Murphy, M. A. 1975: Silurian and Devonian graptolites of central Nevada. Univ. Calif. Publs geol. Sci. 110: 1-109. 
Berry, W. B. N. \& Wilde, P. 1978: Progressive ventilation of the oceans - an explanation for the distribution of the Lower Paleozoic black shales. Am. J. Sci. 278: 257-275.

Bjerreskov, M. 1975: Llandoverian and Wenlockian graptolites from Bornholm. Fossils and Strata 8: 94 pp.

Bjerreskov, M.: Silurian graptolites from North Greenland. $J$. geol. Soc. Lond. In press.

Bouček, B. 1933: Monographie der obersilurischen Graptolithen aus der Familie Cyrtograptidae. Trav. Inst. Géol. Paléont. Univ. Charles Praha 1: 84 pp.

Brochwicz-Lewiǹski, W. Pożaryski, W. \& Tomczyk, H. 1981: Mouvements coulissants de grande ampleur au Paléozoíque inférieur le long de la marge sud-ouest de la plateforme Est-Européenne. C. R. Acad. Sc. Paris, t. 293, 2: $855-858$.

Bouma, A. H. 1962: Sedimentology of some Flysch Deposits. Amsterdam, Elsevier Publ, Co.: 168 pp.

Byström, A. M. 1956: Mineralogy of the Ordovician bentonite beds of Kinnekulle, Sweden. Sver. Geol. Unders. C 540: $62 \mathrm{pp}$.

Christensen, O. B. 1971: Øvre Silur i dybdeboringen Nøvling nr. 1 i Midtjylland. Rapp. Danm. Geol. Unders. 7: 24 pp.

Dadlez, R. 1974: Some geological problems of the Southern Baltic Basin. Acta geol. pol. 24: 261-275.

Elles, G. L. \& Wood, E. M. R. 1901-1918: A monograph of British graptolites. Palaeontogr. Soc. (Monogr.): $539 \mathrm{pp}$.

Erdtmann, B.-D. 1976: Ecostratigraphy of Ordovician Graptoloids. In: Bassett, M. G. (ed.): The Ordovician System: Proceedings of a Palaeontological Association symposium, Birmingham, September 1974. University of Wales Press and National Museum of Wales, Cardiff: 621-643.

Ewart, A., Hildreth, W. \& Carmichael, I. S. E. 1975: Quaternary Acid Magma in New Zealand. Contr. Mineral. Petrol. 51: 1-28.

Fiske, R. S. 1963: Subaqueous pyroclastic flows in the Okanapecosh Formation, Washington. Geol. Soc. Am. Bull. 74: 391-406.

Greiling, L. 1958: Das Gotlandium des Frankenwaldes (Bayerische Entwicklung). Geol. Jb. 73: 301-356.

Gry, H. 1977. Bornholm, Prequaternary map in: Geologi på Bornholm. Varv ekskursionsforer, nr. 1. 2nd ed.: 4-5.

Hagemann, F. 1966: Silurian Bentonites in the Oslo Region. Norg. Geol. Unders. 242: 44-61.

Heiken, O. H. 1974: An atlas of volcanic ash. Smithson. Contr. Earth Sci. 12: 101 pp.

Hildreth, W. 1979: The Bishop Tuff: Evidence for the origin of compositional zonation in silicic magma chambers. Geol. Soc. Am. Spec. Pap. 180: 43-75.

Hills, E. S. \& Thomas, D. E. 1954: Turbidity currents and the graptolitic facies in Victoria. J. geol. Soc. Aust. 1: 119133.

Horny, R. 1960: De Fazielle und biostratigraphische Entwicklung des Silurs in Barrandium. Prager Arbeitstagungen über die Stratigraphie des Silurs und des Devons (1958): 247-257.

Huang, T. C. 1980: A volcanic sedimentation model: implications of processes and responses of Deep-Sea ashes. $\mathrm{Ma}$ rine Geology 38: 103-122.

Jaworowski, K. 1971: Sedimentary structures of the Upper Silurian siltstones in the Polish Lowland. Acta geol. pol. 21: 519-571.

Jürgenson, E. 1964: Silurian metabentonites in the Estonian SSR. In: Litologiya Paleozcyskikh ortlozheniy Estonii. Eesti NSV Teaduste Akadeemia Geoloogia Instituut, Talinn: 87-100. (In Russian with English summary.

Kaljo, D. \& Jürgenson, E. 1977: Sedimentary facies of the East Baltic Silurian. In: D. Kaljo (ed.): Facies and fauna of the Baltic Silurian: 122-148 (In Russian with English summary).
Keller, J. \& Villari, L. 1972: Rhyolitic ignimbrites in the region of Afyon (Central Anatolia). Bull. volcan. 36: 342-358.

Larsen, O. 1971: Kalium/Argon datering af prover fra danske dybdeboringer. Dansk geol. Foren. Arsskrift for 1971: 90-94.

Laufeld, S., Bergström, J. \& Warren, P. T. 1975: The boundary between the Silurian Cyrtograptus and Colonus Shales in Skåne, southern Sweden. Geol. För. Stockh. Förh. 97: 207-222.

Laufeld, S. \& Jeppsson, L. 1976: Silification and bentonites in the Silurian of Gotland. Geol. För. Stockh. Förh. 98: 31-44.

Laursen, D. 1943: Cyrtograptusskifrene paa Bornholm. 2. Læsaa. Danm. Geol. Unders. II rk. 70: 19 pp.

Ledbetter, M. T. \& Sparks, R. S. J. 1979: Duration of large-magnitude explosive eruptions deduced from graded bedding in deep-sea ashlayers. Geology 7: 240-244.

Lindström, M. 1960: On Some Sedimentary and Tectonic Structures in the Ludlovian Colonus Shale of Scania. Geol. För. Stockh. Förh. 82: 318-341.

Lindström, M. 1971: Vom Anfang, Hochstand und Ende eines Epikontinentalmeeres. Geol. Rundsch. 60: 419-438.

Lowe, D. R. 1976: Subaqueous liquefied and fluidized sediment flows and their deposits. Sediment. 23: 285-308.

Magnusson, N. H., Lundquist, G. \& Regnèll, G. 1963: Sveriges Geologi. Svenska Bokförlaget, Norstedts, Stockholm: 698 pp.

Michelsen, O. \& Andersen, C. 1981: Überblick über die regionale Geologie und Tektonik Dänemarks. $Z$. angew. Geol. 27: 171-176.

Middleton, G. \& Hampton, M. 1973: Sediment gravity flows: Mechanics of flow and deposition. In: Turbidites and deep water sedimentation: SEPM short course: 1-38.

Moors, H. T. 1969: The position of graptolites in turbidites. Sediment. Geol. 3: 241-261.

Mutti, E. 1977: Distinctive thin-bedded turbidite facies and related depositional environments in the Eocene Hecho Group (South Central Pyrenees, Spain). Sediment. 24: 107-132.

Nilsson, R. 1946: Bidrag til kännedomen om cyrtograptusskiffer i Röstånga. Geol. För. Stockh. Förh. 68: 372.

Nielsson, R.V. 1979: A boring through the Ordovician-Silurian boundary in western Scania, southern Sweden. Sver. geol. Unders. C 766: 1-18.

Nikiforova, O. I. \& Predtechenskij, N. N. 1968: A Guide to the Geological Excursion on Silurian and Lower Devonian Deposits of Podolia (Middle Dnstr River). VSEGEI, Leningrad: $58 \mathrm{pp}$.

Ninkovich, D., Sparks, R. S. J. \& Ledbetter, M. T. 1978: The exceptional magnitude and intensity of the Toba eruption, Sumatra: An example of the use of deep-sea tephra layers as a geological tool. Bull. volcan. 41: 286-298.

Nyers, A. \& Nilsson, R. 1973: The lithology, fauna and stratigraphy of two drill cores from the Upper Wenlock in western Skåne, southern Sweden. Geol. För. Stockh. Förh. 95: 229-235.

Poulsen, C. 1974: Further contributions to the knowledge of the Palaeozoic of Slagelse no. 1, Western Sealand. Danm. Geol. Unders. II rk. 101: $42 \mathrm{pp}$.

Poulsen, C. \& Poulsen, V. 1967: Neksø-sandsten og lag fra Jordens oldtid. In: Danmarks Natur 1, Politikens Forlag: 49-82.

Poulsen, V. 1966: Cambro-Silurian Stratigraphy of Bornholm. Meddr dansk Geol. Foren. 16: 117-137.

Pribyl, A. 1943: Revision aller Vertreter der Gattung Pristiograptus aus der Gruppe $P$. dubius und $P$. vulgaris aus dem böhmischen und ausländischen Silur. Bull. int. Acad. tchèque Sci. 44: 33-81. 
Rasmussen, L. B., Dinesen, A., Henriksen, S. E., Bang, I., Stenestad, E., Buch, A., Christensen, O. B., Michelsen, O. \& Jacobsen, F. L. 1971: Dybdeboringen Rønde nr. 1 på Djursland. Resultaterne af de geologiske undersøgelser. Danm. Geol. Unders. III rk. 39: 123 pp.

Rasmussen, L. B., Baartman, J. C., Henriksen, S. E., Kristoffersen, F. N., Dinesen, A., Bang, I., Stenestad, E., Buch, A., Christensen, O. B., Michelsen, O., Hansen, T. J. \& Jacobsen, F. L. 1973: Dybdeboringen Novling nr. 1 i Midtjylland. Resultaterne af de geologiske undersøgelser. Danm. Geol. Unders. III rk. 40: 164 pp.

Regnèll, G. \& Hede, J. E. 1960: The Lower Palaeozoic of Scania. The Silurian of Gotland. Int. Geol. Congr. XXI. Sess. Norden 1960: Guide to excursions Nos. A. 22 and C 17: $87 \mathrm{pp}$.

Rhoads, D. C. \& Moorse, J. W. 1971: Evolutionary and ecologic significance of oxygen-deficient marine basins. Lethaia 4 : 413-428.

Rickards, R. B. 1975: Palaeoecology of the Graptolithina, an extinct class of the phylum Hemichordata. Biol. Rev. 50: 397-437.

Rickards, R. B. 1976: The sequence of Silurian graptolite zones in the British Isles. Geol. J. 11: 153-188.

Rosenkrantz, A. 1944: Småbidrag til Danmarks Geologi 1-8. 1. Colonusskifer paa Bornholm. Meddr dansk Geol. Foren.: 10, 436-438.

Schleiger, N. W. 1968: Orientation distribution patterns of graptolite rhabdosomes from Ordovician sediments in Central Victoria, Australia. J. sedim. Petrol. 38: 462-472.

Schleiger, N. W. 1969: Problems in sampling the orientation of fossils in a graptolite band at Eaglehawk, Victoria. Proc. Roy. Soc. Vict. 82: 161-178.

Sigurdsson, H., Sparks, R. S. J., Carey, S. N. \& Haang, T. C. 1980: Volcanogenic sedimentation in the lesser Antilles arc. J. Geol. 88: 523-540.

Smith, A. G., Hurley, A. M. \& Briden, J. C. 1981: Phanerozoic paleocontinental world maps. In: Cambridge Earth Science Series. Cambridge University Press: 102 pp.

Størmer, L. 1967: Some aspects of the Caledonian geosyncline and foreland west of the Baltic Shield. $Q$. Jl. geol. Soc. Lond. 123: 183-214.

Surlyk, F., Hurst, J. M. \& Bjerreskov, M. 1980: First age-diagnostic fossils from the central part of the North Greenland foldbelt. Nature 286: 800-803.

Teller, L. 1969. The Silurian biostratigraphy of Poland based on graptolites. Acta geol. pol. 19: 393-501.

Teller, L. 1976: Morphology of some Upper Wenlockian Cyrtograptinae from Zawada 1 profile (NE Poland). Acta geol. pol. 26: 469-484.

Thorslund, P. 1945: Om bentonitlager i Sveriges kambrosilur. Geol. För. Stockh. Förh. 67: 286-288.
Thorslund, P. 1948a: Silurisk bentonit från Gotland. Geol. För. Stockh. Förh. 70: 345-346.

Thorslund, P. 1948b: - De siluriska lagren oven Pentameruskalkstenen i Jämtland. Sver. Geol. Unders. C 494: 38 pp.

Tomczyk, H. 1962: Problem Stratygrafii Ordowiku i Syluru w Polsce Swietle Ostantnich Badań. Pr. Inst. geol. 35: 1-134.

Tomczyk, H. 1970: The Silurian. In: Geology of Poland I: I. Publishing House Wydawnictwa Geologiczne, Warsaw: 237-320.

Tomczyk, H. \& Tomczykowa, E. 1978: The Development of the Protothethys Ocean and its Influence on the Differentiation of Palaeozoic Deposits in Poland. Bull. Acad. Polon. Sci. Sér. Sci. Geol. Geogra. 26: 103-118.

Törnquist, S. L. 1913: Några anmärkningar om indelningar inom Sveriges kambro-silur. Geol. För. Stockh. Förh. 35: 407-438.

Ui, T. 1971: Genesis of magma and structure of magma chamber of several pyroclastic flows in Japan. J. Fac. Sci. Tokyo Univ.: 53-127.

Ulst, R. 1968: Biostratigraphy and correlation of the Silurian of the middle Baltic Region. In: Grigelis, A. (ed.): Stratigraphy of the Baltic Lower Palaeozoic and its correlation with other areas. Publishing house "Mintis", Vilneus: 215-249 (In Russian with English summary).

Walker, R. G. 1967: Turbidite sedimentary structures and their relationship to proximal and distal depositional environments. J. sedim. Petrol. 37: 25-43.

Walker, G. P. L. 1971: Grain-size characteristics of pyroclastic deposits. J. Geol. 79: 696-714.

Walker, G. P. L. \& Croasdale, R. 1971: Two plinian-type eruptions in the Azons, J. Geol. Soc. 127: 17-55.

Watkins, R. \& Berry, W. B. N. 1977: Ecology of a Late Silurian fauna of graptolites and associated organisms. Lethaia 10: 267-286.

Wærn, B. 1948: The Silurian strata of the Kullatorp Core. In: Wærn, B., Thorslund, P. \& Henningsmoen, G.: Deep Boring Through Ordovician and Silurian Strata at Kinnekulle, Vestergötland. Bull. Geol. Instn. Uppsala 32: 433-474.

Wern, B. 1960: Bentonites and long-distance correlation. Geol. För. Stockh. Förh. 82: 342-344.

Ziegler, P. A. 1978: North-Western Europe: tectonics and basin development. In: A. J. von Loon (ed.): Key-notes of the MEGS-II (Amsterdam, 1978). Geol. Mijnbouw. 57: 578-626.

Ziegler, P. A. 1981: Evolution of Sedimentary Basins in NorthWest Europa. In: Illing, L. V. \& Hobson, G. D. (ed.): Petroleum Geology of the Continental Shelf of North-West Europe. Inst. of Petrol., London: 3-39. 